\title{
Parâmetros limnológicos e microbiológicos do rio Machado e afluentes nas proximidades da cidade de Presidente Médici, Rondônia, Brasil
}

O rápido crescimento da população urbana e da industrialização submete os recursos hídricos a graves pressões. Além disso, o rio Machado recebe lançamentos de esgoto sem tratamento por parte de populações ao longo da bacia hidrográfica. Por isso, o objetivo desse estudo foi avaliar os parâmetros limnológicos e microbiológicos da água do rio Machado e de três córregos nas proximidades da cidade de Presidente Médici, Rondônia-Brasil. Os sete pontos de coleta foram estabelecidos a partir do curso do rio Machado e afluentes, baseados na facilidade de acesso. Os resultados obtidos foram submetidos à ANOVA e a comparação entre as médias pelo teste de Tukey (a $=0,05)$ para verificar as áreas menos preservadas. Para a avaliação da qualidade da água em períodos hidrológicos distintos (cheia e seca), os dados obtidos foram submetidos ao teste T de Student ( $a=0,05)$. Foram observadas alterações pontuais em alguns parâmetros limnológicos. Porém, em geral, apresentaram-se conforme os limites de variação das normatizações vigentes. A sazonalidade influenciou diretamente no pH, temperatura, concentração de oxigênio dissolvido, transparência e concentração amoniacal. Em relação ao $\mathrm{pH}, \sim 4 \%$ das amostras apresentaram-se abaixo do estipulado pela resolução CONAMA 357/2005 de águas doce de classe 2. Para o oxigênio dissolvido, apenas uma amostra apresentou abaixo do estabelecido pela mesma legislação. Os parâmetros limnológicos e microbiológicos dos pontos mais próximos da área urbana apresentaram resultados mais alarmantes devidos muito provavelmente a poluição difusa. Os teores de coliformes totais e termotolerantes apresentaram-se abaixo do limite da legislação em todos os pontos analisados. O estudo indica que há necessidade de gerar informações sobre a qualidade das águas dos rios e córregos no estado de Rondônia, sobretudo, dos cursos d'água próximos as áreas urbanas. Porque são informações importantes para saúde e abastecimento público, bem como a saúde ambiental.

Palavras-chave: Coliformes totais; Escherichia coli; Qualidade da água; Recursos hídricos; Saúde pública.

\section{Limnological and microbiological parameters of Machado river and afluents near the city of Presidente Médici, Rondônia, Brazil}

The rapid growth of the urban population and industrialization puts water resources under severe pressure. In addition, the Machado River receives untreated sewage from population along the river basin. Therefore, the aimed of this study was to evaluate the limnological and microbiological parameters of the water of the Machado river and of three streams in the vicinity of the city of Presidente Médici, Rondônia-Brazil. The seven collection points were established from the course of the Machado River and tributaries, based on ease of access. The results obtained were submitted to ANOVA and the comparison between the averages by the Tukey test $(a=0.05)$ to verify the less preserved areas. For the assessment of water quality in different hydrological periods (full and dry) the data obtained were submitted to Student's T test $(a=0.05)$. Occasional changes were observed in some limnological parameters. However, in general, they were within the limits of variation of the current resulions. concentration. In relation to $\mathrm{pH} \sim 4 \%$ of the samples were below what was stipulated by CONAMA resolution 357/2005 for freshwater class 2 . For dissolved oxygen, only one sample presented below that established by the same legislation. The limnological and microbiological parameters of the points closest to the urban area, presented more alarming results, most likely due to diffuse pollution. The levels of total and thermotolerant coliforms were below the limit of the legislation in all analyzed points. The study indicates that there is a need to generate information on the quality of the water in rivers and streams in the state of Rondônia, above all, in watercourses close to urban areas. Because they are important information for health and public supply, as well as environmental health.

Keywords: Total coliforms; Escherichia coli; Water quality; Water resources; Public health.

Topic: Engenharia Ambiental

Reviewed anonymously in the process of blind peer.
Received: 15/04/2021

Approved: 16/05/2021
Rute Bianchini Pontuschka (1D

Universidade Federal de Rondônia, Brasil

http://lattes.cnpq.br/0019860541206945 http://orcid.org/0000-0002-3789-1252 rutepont@unir.br

\section{Vinícius Gotardi Rocha}

Universidade Federal de Rondônia, Brasi http://lattes.cnpq.br/5635488397968373 rutepont@unir.br

\section{Silmar Mendes dos Santos}

Universidade Federal de Rondônia, Brasil

http://lattes.cnpq.br/3112792343418707 rutepont@unir.br

Nicholas Brito Alonso (iD)

Universidade Federal de Rondônia, Brasil http://lattes.cnpq.br/3293191395221039 http://orcid.org/0000-0002-0088-4825 nicholasbrito11@gmail.com

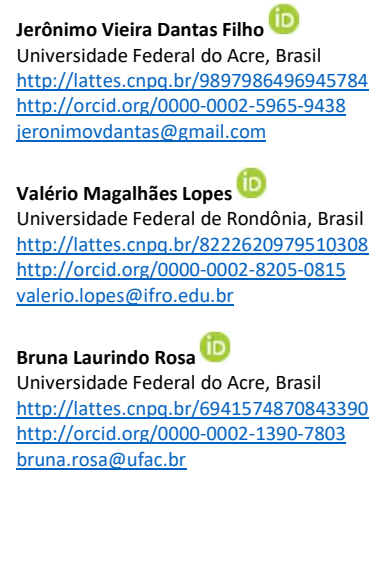
p.//lattes.cnpq.br/989798649694578 eronimovdantas@gmail.com

alério Magalhães Lopes (ID) Universidade Federal de Rondônia, Brasil tp://lattes.cnpg.br/8222620979510308 valerio.lopes@ifro.edu.br

Bruna Laurindo Rosa ID

ral do Acre, Bras ttp://lattes.cnpq.br/6941574870843390 http://orcid.org/0000-0002-1390-7803 bruna.rosa@ufac.br

\section{Elvino Ferreira (iD) \\ Universidade Federal de Rondônia, Brasil http://lattes.cnpq.br/2112546227356585 http://orcid.org/0000-0001-9174-8468 elvino@uir.br \\ Jucilene Cavali (iD) \\ Universidade Federal de Rondônia, Brasil http://lattes.cnpq.br/3950218993166956 http://orcid.org/0000-0002-2069-4543 icavali@unir.b. \\ Fernanda Bay Hurtado (iD) \\ Universidade Federal de Rondônia, Brasil http://lattes.cnpq.br/9700422467259382 http://orcid.org/0000-0001-7593-1852 fernandabay@unir.br}

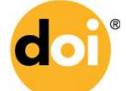

DOI: 10.6008/CBPC2179-6858.2021.005.0032
Referencing this:

PONTUSCHKA, R. B.; ROCHA, V. G.; SANTOS, S. M.; ALONSO, N. B.; DANTAS FILHO, J. V.; LOPES, V. M.; ROSA, B. L.; FERREIRA, E.; CAVALI, J.; HURTADO, F. B.. Parâmetros limnológicos e microbiológicos do rio Machado e afluentes nas proximidades da cidade de Presidente Médici, Rondônia, Brasil. Revista Ibero Americana de Ciências Ambientais, v.12, n.5, p.387-408, 2021. DOI:

http://doi.org/10.6008/CBPC2179-6858.2021.005.0032 


\section{INTRODUÇÃO}

O Brasil encontra-se em uma situação confortável em relação aos recursos hídricos no quesito quantidade de maneira nacional, mas em determinadas regiões do nordeste e sudeste existem problemas de qualidade de água para abastecimento (PIRATOBA et al., 2017). Entretanto, mesmo dispondo de recurso hídrico abundante, a distribuição espacial desigual no território brasileiro e a má utilização indicam que o país não está livre da ameaça de uma crise de abastecimento (WREGE et al., 2016). Essa distribuição é geralmente expressa por região, sendo a região Norte a que possui maior disponibilidade de recursos hídricos, chegando a 68\%. O estado de Rondônia tem significativa contribuição hidrográfica neste percentual, porque se localiza em uma área fluvial com extensão de $1.500 \mathrm{~km}$, destacando-se os rios Madeira, Mamoré, Guaporé e Machado (COSTA et al., 2015).

O rio Machado tem aproximadamente $1.200 \mathrm{~km}$ de extensão e deságua à margem direita do rio Madeira (KRUSCHE et al., 2005; SANTIAGO et al., 2015). O regime de cheias dos rios amazônicos ocorre entre novembro e dezembro, sendo o período de alta pluviosidade entre janeiro e março, com maior nível em fevereiro; a época de vazante ocorre entre abril e julho, com período de baixa entre agosto e outubro, atingindo o nível mínimo em setembro (SOUSA et al., 2017). O percurso do rio Machado ocorre pela região Central de Rondônia, banhando alguns municípios como Pimenta Bueno, Cacoal, Presidente Médici, JiParaná e outros, de modo que esses municípios usam a água deste rio para o abastecimento da população (PROSENEWICZ, 2012).

Dentro da bacia do rio Machado há muitas propriedades rurais onde predominam atividades agropecuárias (ANDRADE et al., 2019; GALVAN et al., 2020). Segundo Gomes et al. (2015), o uso dessas águas para irrigação e fornecimento ao gado causa enormes prejuízos à mata ciliar e potencializa ainda mais o processo de erosão e contaminação dos cursos d'água. Vale lembrar que o uso de agrotóxicos nitrogenados na agricultura praticada aos arredores dos rios causa aumento de compostos tóxicos na água, como o nitrato, originado por meio da ação de bactérias nitrificantes que fazem parte do ciclo do nitrogênio (HAN et al., 2017; GALVAN et al., 2020). A Lei 9.974, de 06 de junho de 2000, estabeleceu diretrizes para o recolhimento das embalagens vazias de agrotóxicos. A partir deste documento baseado no conceito de logística reversa, o Brasil iniciou um programa de processamento de embalagens que é referência mundial. No entanto, a contaminação dos leitos hídricos acabou ficando prejudicada.

Na Amazônia brasileira, mais especificamente, a vegetação do estado de Rondônia sofreu amplamente aos efeitos decorrentes do desmatamento. Adicionalmente, entre 2004 e 2020 o desmatamento acumulou $62.936,00 \mathrm{~km}^{2}(13.76 \%)$ do território rondoniense segundo o Instituto Nacional de Pesquisas Aeroespaciais (INPE, 2020). A taxa de desmatamento em Rondônia no ano de 2020, segundo o INPE atingiu 1.259,00 $\mathrm{km}^{2}$ (INPE, 2020). O nível mais alto de desmatamento ocorreu na bacia do rio Machado, devido sua proximidade com a rodovia BR-364 (COSTA et al., 2015).

Assim, o rápido crescimento da população urbana e da industrialização submete a graves pressões aos recursos hídricos. A ação do homem neste ecossistema compromete a qualidade da água e tem suas 
principais origens nas práticas não sustentáveis da agropecuária e na disposição inadequada de dejetos sólidos e líquidos, gerados por atividades domésticas e industriais (NAQVI et al., 2015). O crescimento urbano gera o desmatamento que, consequentemente, acelera o processo de erosão, contaminação microbiológica e química dos cursos d'água (COSTA et al., 2015). Além disso, o rio Machado recebe lançamentos de esgoto sem tratamento por parte de populações ao longo da bacia hidrográfica (BARBOSA; SILVA FILHO, 2018).

O que se observa atualmente é que o crescimento rápido das cidades não vem sendo acompanhado no mesmo ritmo pelo atendimento de infraestrutura e melhoria da qualidade de vida, e essa deficiência é comum na maioria das cidades brasileiras (CONSERVA et al., 2019). Além disso, a política de saneamento ambiental seguida é a de canalizar e/ou retificar os rios e córregos. Essa forma de urbanização adotada ao longo desta bacia hidrográfica vem causando muitos problemas ambientais (BRUM et al., 2016). A utilização da água para um determinado propósito não deve prejudicar os diversos usos possíveis, entre os quais figuram aspectos culturais, atividades recreativas e a preservação da diversidade biológica (GOMES et al., 2015). Em consequência, surge a necessidade de monitorar os cursos hídricos a fim de disponibilizar informações que permitam propor medidas adequadas de manejo para manter os ambientes aquáticos com qualidade ecológica (LIMA et al., 2016). Por isso, indicadores limnológicos e microbiológicos são utilizados para verificar a qualidade dos de corpos d'água (WU, 2018). Diante dos pressupostos apresentados, o objetivo desse estudo foi avaliar os parâmetros limnológicos e microbiológicos da água do rio Machado e de três córregos nas proximidades da cidade de Presidente Médici - Rondônia - Brasil.

\section{METODOLOGIA}

A pesquisa foi conduzida por equipe pertencente à Universidade Federal de Rondônia (UNIR) e as análises realizadas no Laboratório de Química do Instituto Federal de Educação, Ciência e Tecnologia de Rondônia (IFRO). O trabalho foi desenvolvido proximamente à cidade de Presidente Médici, que está situada na região central do estado de Rondônia, Amazônia Ocidental-Brasil. A cidade está localizada entre os paralelos de 070 58' e 13 43' de latitude Sul e os meridianos de 59o 50' e 66 $48^{\prime}$ de longitude Oeste (Figura 3). O município de Presidente Médici está inserido na bacia do rio Machado, que por sua vez, nasce e termina em solo rondoniense. Suas nascentes estão localizadas na Chapada dos Parecis, no Planalto de Vilhena, onde nascem os Rios Pimenta Bueno ou Apidiá (nome indígena) e Barão de Melgaço ou Comemoração de Floriano, que vão se juntar à altura da cidade de Pimenta Bueno.

O rio Machado percorre o estado de Rondônia no sentido Sudeste-Norte, desembocando no rio Madeira, próximo à Vila de Calama, no município de Porto Velho, Rondônia. Segundo o sistema de classificação de Köppen, o clima predominante da região supracitada é do tipo Aw - Clima Tropical Chuvoso, com média climatológica da temperatura do ar durante o mês mais frio superior a $18{ }^{\circ} \mathrm{C}$ (megatérmico) e um período de seca bem definido durante o inverno, momento em que ocorre um moderado déficit hídrico com índices pluviométricos inferiores a $50 \mathrm{~mm} / \mathrm{mês}$. A média anual da precipitação pluvial varia entre 1.400 e 2.600 mm/ano, enquanto a média anual em 2014 a 2015, a 
temperatura do ar varia entre 24 e $26^{\circ} \mathrm{C}$.

O estado de Rondônia encontra-se sob a influência de anticiclones que se formam nas altas latitudes e que atravessam a Cordilheira dos Andes em direção ao sul do Chile. Alguns destes anticiclones são excepcionalmente intensos, condicionando a formação de aglomerados convectivos que intensificam a formação dos sistemas frontais na região Sul do país. Tais sistemas deslocam-se em direção à região amazônica causando o fenômeno conhecido regionalmente como friagem. Durante os meses de friagem, as temperaturas mínimas do ar podem atingir valores inferiores a 6ํㅡ. Devido à curta duração do fenômeno, não influencia, sobremaneira, nas médias climatológicas da temperatura mínima do ar (SEDAM, 2007).

Os sete pontos de coleta de água próximos da cidade de Presidente Médici, Rondônia-Brasil (Figura 1) foram estabelecidos a partir do curso do rio Machado e afluentes, baseados na facilidade de acesso. São locais caracterizados como fontes influenciadas pela ação antrópica (Tabela 1) proveniente do ambiente rural e urbano, com presença de atividades industriais. Além disso, foi observado o raio da Área de Preservação Permanente (APP) segundo o código florestal brasileiro, Lei 12651/2012 (Tabela 2). As coletas eram feitas sempre entre 7 horas da manhã e meio dia, iniciando no ponto 1, sendo o ponto 7 o último.

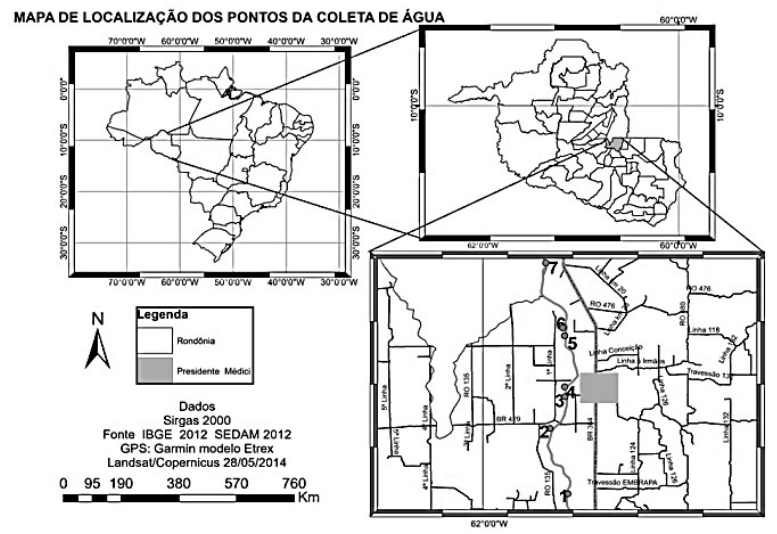

Figure 1: Localização geográfica dos pontos de coleta das amostras de água do rio Machado e córregos próximos da cidade de Presidente Médici, RO, Brasil.

Tabela 1: Descrição e coordenadas geográficas dos pontos de amostragem do Rio Machado e córregos próximos da cidade de Presidente Médici, RO, Brasil.

\begin{tabular}{|c|c|c|c|}
\hline \multirow[t]{2}{*}{$\begin{array}{l}\text { Pontos de } \\
\text { amostragem }\end{array}$} & \multirow[t]{2}{*}{ Descrição } & \multicolumn{2}{|c|}{$\begin{array}{l}\text { Coordenadas } \\
\text { geográficas }\end{array}$} \\
\hline & & Latitude & Longitude \\
\hline Ponto 1 & $\begin{array}{l}\text { Cachoeira dos patos: ponto mais afastado da área urbana, sentido município de Cacoal, apresenta um raio de } \\
200 \mathrm{~m} \text { de mata ciliar conservada. A área de pastagem mais próxima está localizada na margem direita, a cerca de } \\
250 \mathrm{~m} \text { de distância do ponto de coleta. Está a } 700 \mathrm{~m} \text { da rodovia Pastor Severo Antônio de Araújo (RO-135). }\end{array}$ & S $11^{\circ} 56^{\prime} 19^{\prime \prime}$ & $W 61^{\circ} 56^{\prime} 22^{\prime \prime}$ \\
\hline Ponto 2 & $\begin{array}{l}\text { Córrego Taboca: área próxima à calha do rio Machado, apresenta um raio com cerca de } 150 \mathrm{~m} \text { de mata ciliar } \\
\text { conservada. A área de pastagem mais próxima está localizada a cerca de } 200 \mathrm{~m} \text { do ponto de coleta. Quanto à } \\
\text { distância das rodovias, está a } 750 \mathrm{~m} \text { da BR- } 429 \text { e a } 1100 \mathrm{~m} \text { da RO- } 135 \text {. O percurso a leste da rodovia RO-135 } \\
\text { encontra-se degradado devido à presença de pastagens que atingem suas margens. }\end{array}$ & S $11^{\circ} 12^{\prime} 27^{\prime \prime}$ & $W 61^{\circ} 56^{\prime} 38^{\prime \prime}$ \\
\hline Ponto 3 & $\begin{array}{l}\text { Captação de água da Companhia de Águas e Esgoto de Rondônia (CAERD): área próxima a calha do rio } \\
\text { Machado, apresenta um raio de } 140 \text { m de mata ciliar conservada a esquerda } 80 \text { m e uma área mais degradada a } \\
\text { direta, } 40 \mathrm{~m} \text {. A área de pastagem mais próxima está localizada a cerca de } 40 \mathrm{~m} \text {. A } 750 \mathrm{~m} \text { encontrasse área } \\
\text { urbana. }\end{array}$ & $\mathrm{S} 11^{\circ} 10^{\prime} 30^{\prime \prime}$ & W $11^{\circ} 10^{\prime} 39^{\prime \prime}$ \\
\hline Ponto 4 & $\begin{array}{l}\text { Córrego Primavera: área próxima a calha do rio Machado, apresenta um raio de } 140 \text { m de mata ciliar } \\
\text { conservada. A área de pastagem mais próxima está localizada a cerca de } 160 \text { m. A } 180 \text { m encontra-se uma } \\
\text { propriedade com atividade agrícola, com cultivo de café. }\end{array}$ & $\mathrm{S} 11^{\circ} 10^{\prime} 01^{\prime \prime}$ & $W 61^{\circ} 55^{\prime} 46^{\prime \prime}$ \\
\hline Ponto 5 & $\begin{array}{l}\text { Córrego Leitão: área próxima à calha do rio Machado, em sua margem direita há cerca de } 60 \mathrm{~m} \text { de mata ciliar } \\
\text { conservada. Quanto à margem esquerda, há uma incidência de } 150 \mathrm{~m} \text { de área conservada. Apresenta ao longo } \\
\text { de seu leito atividade de extração de areia, presença de uma suinocultura, balneário e laticínio. Percorre extensa } \\
\text { área rural com pequena ocorrência de mata ciliar, além de cortar a rodovia BR-364. Há } 120 \mathrm{~m} \text { do ponto de coleta } \\
\text { há área de pastagem. }\end{array}$ & S $11^{\circ} 07^{\prime} 51^{\prime \prime}$ & W $61^{\circ} 55^{\prime} 18^{\prime \prime}$ \\
\hline
\end{tabular}




\begin{tabular}{|c|c|c|c|}
\hline Ponto 6 & $\begin{array}{l}\text { Fábrica de Heparina: margem direita possui cerca de } 150 \mathrm{~m} \text { de área preservada com incidência de uma lagoa } \\
\text { natural. Na sua margem esquerda há uma ilha parcialmente conservada, com uma extensão de } \\
\text { aproximadamente } 2600 \mathrm{~m} \text { e largura de } 500 \mathrm{~m} \text { baseado no ponto de coleta. A área de pastagem mais próxima } \\
\text { está localizada a } 190 \mathrm{~m} \text {. As lagoas de decantação de uma empresa estão localizadas na margem direita, há cerca } \\
\text { de } 850 \text { metros da calha principal. }\end{array}$ & $S 11^{\circ} 07^{\prime} 31^{\prime \prime}$ & W $61^{\circ} 55^{\prime} 24^{\prime \prime}$ \\
\hline Ponto 7 & $\begin{array}{l}\text { Curtume: margem esquerda apresenta pequena incidência de mata ciliar, com presença de grande área de } \\
\text { pastagens. Margem direita possui área superior a } 250 \text { m de mata conservada, apresenta, lagoa de decantação e } \\
\text { uma estrada de acesso às casas de manutenção da tubulação que carreia o efluente da lagoa de decantação da } \\
\text { empresa até a calha principal do rio Machado. }\end{array}$ & S $11^{\circ} 03^{\prime} 57^{\prime \prime}$ & W $61^{\circ} 56^{\prime} 53^{\prime \prime}$ \\
\hline
\end{tabular}

*Os pontos foram marcados com o Global Position System (GPS) da marca Garmin modelo etrex, para a obtenção das coordenadas geográficas.

Tabela 2: Área de Preservação Permanente (APP) segundo o código florestal brasileiro, Lei 12651/2012.

\begin{tabular}{ll}
\hline Largura da APP & Rios (Largura) \\
\hline $30 \mathrm{~m}$ & Com menos de $10 \mathrm{~m}$ \\
$50 \mathrm{~m}$ & De $10 \mathrm{~m}$ a $50 \mathrm{~m}$ \\
$100 \mathrm{~m}$ & De $50 \mathrm{~m}$ a 200 \\
$200 \mathrm{~m}$ & De $200 \mathrm{~m}$ a $600 \mathrm{~m}$ \\
$500 \mathrm{~m}$ & Com mais de $600 \mathrm{~m}$ \\
\hline
\end{tabular}

Fonte: Lei n. 12.651, de 25 de maio de 2012; Código Florestal Brasileiro.

Em cada ponto foram realizadas medidas na coluna d'água, em três profundidades, $20 \mathrm{~cm}$ da superfície, do meio e ao fundo da coluna d'água, em outras palavras, as coletas foram realizadas em triplicata. Foram realizadas 11 coletas mensais, em diferentes pontos, sendo quatro no rio Machado e três nos córregos próximos da cidade de Presidente Médici, totalizando 231 amostras de água analisadas de sete locais diferentes com aproximadamente $27 \mathrm{~km}$ de percurso entre o primeiro ponto e o último (Figuras $3,4$ e 5$)$.

Para realização da coleta foi empregada uma garrafa de Van Dorn feita de tubo PVC, previamente higienizada. Para as análises da coluna d'água a garrafa foi mergulhada com a boca para baixo, para a coleta de meio e fundo. Vale destacar que conforme as sugestões de Parron et al. (2011), não foram coletadas amostras próximas à margem nem em áreas estagnadas do rio e/ou córrego. Para avaliar os parâmetros físico-químicos da água foi utilizada uma sonda de multiparamétrica previamente calibrada (sensor-direct 150, LOVIBOND) para as seguintes variáveis limnológicas: potencial hidrogeniônico (pH), temperatura $(\underline{O} C)$, oxigênio dissolvido em água (ODA) $(\mathrm{mg} / \mathrm{L})$ e condutividade elétrica em água (CEA) $(\mu \mathrm{S} / \mathrm{cm})$, seguindo as recomendações compiladas por Opiyo et al. (2018).

Cabe destacar que a transparência da água $(\mathrm{cm})$ foi determinada in situ com o uso do disco de Secchi, que foi submerso na água para realização das medições. A concentração amoniacal total (CAT) ( $\mathrm{mg} / \mathrm{L} \mathrm{N}-\mathrm{NH}_{3}$ ) foi verificada in situ por meio do Alfakit, seguindo as recomendações de Barros et al. (2010) e Souza Filho et al. (2020). Os dados de pluviosidade foram obtidos por meio da Empresa Brasileira de Pesquisa Agropecuária (EMBRAPA). Os dados obtidos nas leituras dos parâmetros limnológicos, foram avaliados seguindo os valores estipulados na Resolução CONAMA N³57/2005. No presente estudo, o mês de setembro foi incluído no período de seca devido à similaridade de seu índice pluviométrico ao período seco, e ainda, o mês de maio foi considerado como pertencente ao período de cheia devido ao elevado índice pluviométrico.

Foram realizadas 11 coletas mensais nos diferentes pontos de amostragem, sendo quatro no rio Machado e três nos córregos próximos à cidade de Presidente Médici. Totalizando 70 amostras analisadas de sete locais diferentes com aproximadamente $27 \mathrm{~km}$ de percurso entre o primeiro ponto e o último 
ponto (Figuras 3, 4 e 5). Para realização da coleta, seguiram-se as recomendações da Fundação Nacional da Saúde (FUNASA), de forma que foram usados frascos de vidro com boca larga previamente esterilizados. $A$ garrafa foi mergulhada com a boca para baixo, de 15 a $30 \mathrm{~cm}$ abaixo da superfície da água, sendo aberta apenas dentro da água (BRASIL, 2006). Em cada ponto de coleta foi retirada uma amostra de $250 \mathrm{~mL}$ de água. Mas, não foram coletadas amostras próximas à margem nem em áreas estagnadas do rio, conforme recomendações de Targa et al. (2012). Após a coleta, o frasco foi acondicionado sob refrigeração e seguiu para análise.

A área de trabalho foi desinfetada com etanol $70 \%$. Todos os utensílios e instrumentos usados foram previamente esterilizados em autoclave, estufa de esterilização ou flambados no momento do uso. Para a quantificação dos coliformes totais e termotolerantes utilizou-se a técnica do número mais provável (NMP), também conhecida como método dos tubos múltiplos, devido às condições da pesquisa, adotou-se o emprego da série de três tubos, descrita no manual da FUNASA (BRASIL, 2006).

O teste presuntivo avalia a presença de microrganismos fermentadores de lactose, especialmente o grupo dos coliformes. O teste baseia-se na utilização de meio de cultura rico em nutrientes (caldo lactosado), que facilita o rápido crescimento dos microrganismos (SILVA et al., 2014). Para cada um dos sete pontos de coleta foram realizadas seis diluições, em triplicata. A primeira diluição consistia na transferência de $1,0 \mathrm{~mL}$ de água da amostra para cada um da série de tubos, em seguida, realizou-se homogeneização e, posteriormente, a segunda diluição, que consiste na transferência de $1,0 \mathrm{~mL}$ de amostra da primeira diluição para cada um dos três tubos. Esse procedimento seguiu até a sexta e última diluição. Os tubos de Durhan invertidos foram incubados entre 35 e 37으 por 24 a 48 horas. Transcorrido este tempo, fez-se a leitura, de modo que os tubos que apresentaram formação de gás foram considerados positivos.

Para este teste utilizou-se o caldo bile verde brilhante (VB), que contém dois inibidores (bile e o corante verde brilhante, derivado do trifenilmetano) do crescimento da microflora acompanhante, especialmente bactérias gram-positivas. A lactose é a fonte de carboidrato deste meio. Assim, a produção de gás nos tubos de Durhan, nas condições do teste, indica que houve desenvolvimento de bactérias gramnegativas que fermentam lactose, característica do grupo coliforme (MACÊDO, 2004).

Dos tubos que apresentaram formação de gás no caldo lactosado foram retiradas alíquotas com alça microbiológica e semeadas em tubos contendo $9 \mathrm{~mL}$ de caldo VB, com tubos de Durhan invertidos. Para o teste confirmativo da presença de coliformes termotolerantes utilizou-se o caldo Escherichia coli (EC), meio confirmativo para coliformes termotolerantes. Assim como o caldo VB, o caldo EC não deve ser usado para isolamento direto de coliformes, porque é necessário um enriquecimento em meio presuntivo para uma boa recuperação dos coliformes termotolerantes (SILVA et al., 2014). Assim sendo, tomou-se uma alçada do meio de cultura dos tubos positivos para o teste presuntivo, que foram transferidas para tubos contendo caldo EC, e esses foram incubados em banho-maria a 44,5 - 45으 durante 48 horas. A positividade do teste foi observada pela produção de gás no interior dos tubos de Durhan.

A classificação dos corpos d'água foi determinada por meio da Resolução CONAMA n 357/2005 
(BRASIL, 2005) para análise de coliformes termotolerantes, e decreto $n^{\circ} 7903 / 1997$ da SEDAM para análise de coliformes totais. Até o momento de realização do estudo o município de Presidente Médici não possuía enquadramento de Comitê de Bacias Hidrográficas, conforme a Resolução CONAMA n 357/2005. Por este motivo, de acordo com o art. 42 dessa resolução, enquanto não aprovados os devidos enquadramentos, as águas doces são consideradas Classe 2. Portanto, os dados obtidos foram qualificados conforme os padrões estabelecidos para essa classe de águas.

Os dados dos parâmetros microbiológicos foram distribuídos entre os períodos hidrológicos de cheia e seca, de acordo com o balanço hídrico climático da região de Presidente Médici. Determinaram-se três meses de deficiência hídrica no solo (junho, julho e agosto) e com excedente entre os meses de outubro a abril, sendo os meses de setembro e maio de transição (SEDAM, 2002). A partir desta classificação foram calculados os valores médios de coliformes entre os períodos de cheia e seca em cada ponto de amostragem. Outro comparativo adotado foi a diferenciação entre pontos em relação às análises mensais.

Os resultados obtidos foram submetidos à análise de variância e a comparação entre as médias dos diferentes pontos de coleta foram realizadas pelo teste de Tukey $(\alpha=0,05)$ para verificar se os dados obtidos nos pontos referentes às áreas mais preservadas diferiam estatisticamente dos obtidos nos pontos que sofrem interferências antrópicas mais intensas. $O$ tratamento adotado foi à comparação entre pontos de coleta. Para a avaliação da qualidade da água em períodos hidrológicos distintos (cheia e seca), os dados obtidos foram submetidos ao teste $T$ de Student $(\alpha=0,05)$ para verificar diferenças entre os pontos nos diferentes períodos hidrológicos de cheia e seca. Cabe salientar que de acordo com a SEDAM (2002), o período considerado como seca foi de agosto a setembro e de março a junho. E, considerado como período de cheia foi de outubro a dezembro e de janeiro a fevereiro.

\section{RESULTADOS E DISCUSSÃO}

Segundo a Secretaria de Estado do Desenvolvimento Ambiental (SEDAM), o período de cheia ocorre de outubro a abril, e o período mais seco em junho, julho e agosto, sendo maio e setembro os meses de transição (Figura 2).

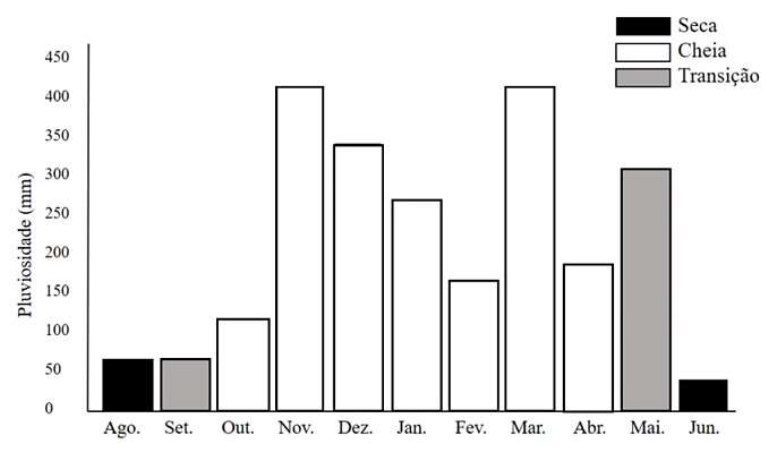

Figura 2: Dados pluviométricos da região dos pontos de coleta, Presidente Médici, RO, Brasil. Fonte: SEDAM (2014).

Os valores de $\mathrm{pH}$ da água dos pontos de amostragem não apresentaram diferenças $(p>0,05)$, tendo 
como base a análise de variância e o teste Tukey $(\alpha=0,05)$. A aferição apresentou valores médios que variaram entre 4,5 e 7,9, como apresentado na Figura 3. Peixoto Filho (2008) avaliou a qualidade da água do córrego Prosa, no município de Campo Grande, no Mato Grosso do Sul, e Abreu et al. (2015) avaliaram a qualidade da água da bacia hidrográfica do rio Jari, no Amapá, obtiveram valores de pH entre 6,0 e 7,0. Segundo Esteves (1998), a maioria dos ecossistemas aquáticos brasileiros apresenta valores de pH entre 6,0 e 8,0, ecossistemas aquáticos com pH ácido causa acidificação, aumento de $\mathrm{CO} 2$, ions de hidrogênio e bicabornato, aumentando as populações aquáticas a gastarem mais energia em seus processos biológicos, amônia ionizada que predomina em pH ácidos.

Ao correlacionar os pontos entre si, tendo como base o teste T de Student $(\alpha=0,05)$ das variações nos diferentes períodos (cheia e seca), não foram encontradas diferenças ( $p>0,05)$ (Figura 3). Porém, ao comparar o pH da água nos períodos de cheia e seca, constatou-se diferença $(p<0,05)$ entre as médias para todos os pontos de coleta. O teste $\mathrm{T}$ indicou valores mais elevados no período de cheia (Figura 3 ). Os menores valores de pH foram registrados no período de transição. Segundo Esteves et al. (2011), com o aumento das chuvas o pH apresenta valores mais altos, pois ocorre diluição dos compostos dissolvidos.

$\mathrm{O} \mathrm{pH}$ da água do ponto 2 (agosto e setembro), ponto 3 (setembro), ponto 4 (setembro), ponto 5 (junho e setembro), ponto 6 (setembro) ponto 7 (agosto e setembro) apresentam variações abaixo de 6,0. A leve acidez foi decorrente as chuvas pontuais que carreia matéria orgânica para a calha hídrica e com os processos de decomposição formam ácidos húmicos e fúlvicos (MAROTTA et al., 2008; ESTEVES, 2011). Mais de $70 \%$ das amostras de água expressaram valores de $\mathrm{pH}$ dentro do limite estipulado pela legislação, o que indica baixa influência da ação antrópica (BRASIL, 2005).

(a)

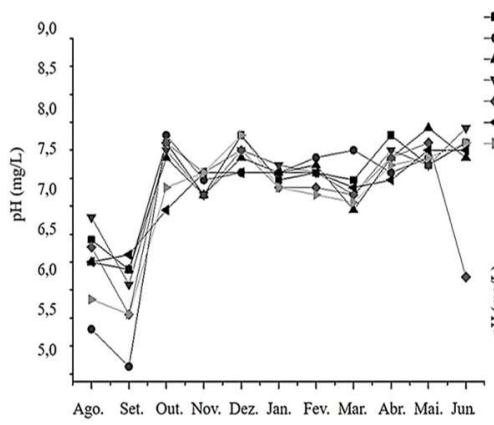

(b)

Ponto 1 Cachoeira de patos - Ponto 2 Igarapé Taboca - Ponto 3 CAERD Ponto 5 lgarapé Primaver - Ponto 5 Igarapé Leit - Ponto 6 Heparina

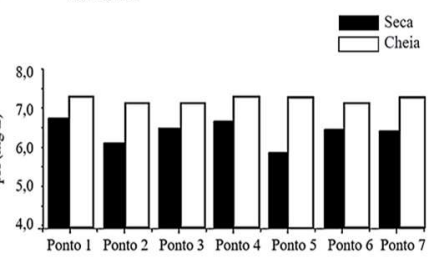

Figura 3: Gráficos expressam os resultados do pH da água. (a) Variações do pH nos pontos de amostragem e (b) Valores médios do pH nos períodos de cheia e seca do rio Machado e córregos próximos da cidade de Presidente Médici, RO, Brasil.

Os valores da temperatura da água dos pontos de amostragem não apresentaram diferenças $(p>0,05)$, tendo como base a análise de variância e o teste Tukey $(\alpha=0,05)$. A aferição apresentou valores médios que variaram entre 25,0 e 31,1 으, como apresentado na Figura 4. Vale salientar que a resolução CONAMA 357/2005 não estipula valores limitantes para temperatura. Entretanto, temperaturas um pouco mais elevadas $(p>0,05)$ foram encontradas da água no ponto $4(26,6 \pm 1,5$ 으), ponto $5(27,7 \pm 2,0$ 으 $)$ e ponto $7(28,0 \pm 3,0$ 으) , localizados em áreas com pouca mata ciliar e cercados por atividade agropecuária. 
Conforme Peixoto Filho (2008) e Herrero et al. (2009), o aumento da temperatura está associado à falta de vegetação, sabendo-se que a radiação solar influência no parâmetro.

Martins (2009) e Alves (2013) ressaltam que a elevação da temperatura pode produzir alterações na solubilidade de gases na água. Para Angelocci et al. (1995) e Alves (2013), quando se tem temperatura elevada em um ambiente aquático há perda de oxigênio dissolvido, influenciando na qualidade da água e, consequentemente, na vida dos organismos aquáticos aeróbicos. Ao comparar os períodos de cheia e seca, constatou-se diferença $(p<0,05)$ entre as médias, estando os maiores valores no período de seca $(p<0,05)$ nos pontos 1,3 e 7, tendo como base a análise de variância e o teste T de Student $(\alpha=0,05)$ (Figura 4). Por meio das observações em campo, foi possível verificar que não só os córregos, mas também os pontos na calha do rio Machado, possuem pouca cobertura de mata ciliar, de forma que, este fator contribuiu para temperaturas mais elevadas. O mesmo resultado foi relatado por Martins (2009) e Abreu et al. (2015), modificações como retirada da cobertura vegetal, principalmente das margens dos sistemas aquáticos, contribuiu para a radiação solar direta, aumentando a temperatura dos corpos hídricos. Segundo Terra et al. (2010) e Hagemann et al. (2015), com o aumento da precipitação e o consequente aumento dos sólidos em suspensão, ocorrem picos nos valores de turbidez nos meses chuvosos, porque esses sólidos dispersos impedem que a luz solar penetre na água, diminuindo a temperatura, o mesmo ocorreu nos pontos 1,3 e 7 deste estudo (Figura 4).

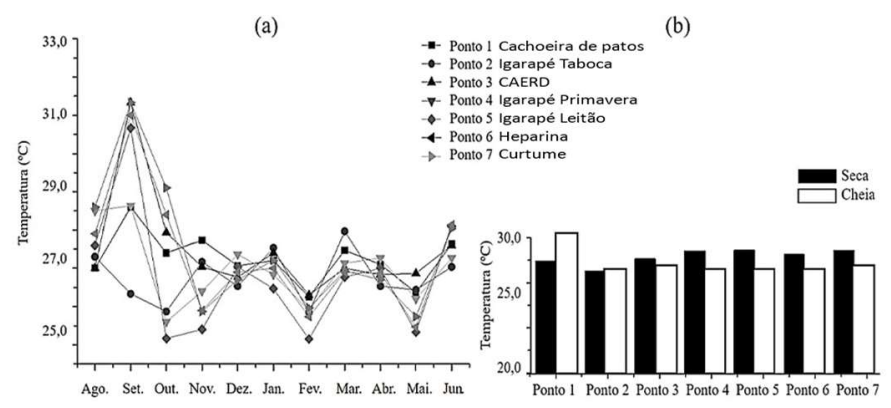

Figura 4: Gráficos expressam os resultados expressam a temperatura da água. (a) Variações do pH nos pontos de amostragem e (b) Valores médios do pH nos períodos de cheia e seca do rio Machado e córregos próximos da cidade de Presidente Médici, RO, Brasil.

Os valores do oxigênio dissolvido da água (ODA) dos pontos de amostragem não apresentaram diferenças $(p>0,05)$, tendo como base a análise de variância e o teste Tukey $(\alpha=0,05)$. A aferição do ODA apresentou valores médios que variaram entre 4,0 a 12,5 mg/L, como apresentado na Figura 5. Essa variação apresenta-se comum aos rios amazônicos (ESTEVES, 2011). Contudo, algumas das médias da concentração do ODA apresentaram-se acima do limite estabelecido pela Resolução CONAMA no 357/2005 para corpos de água doce de Classe 2 ( $\geq 5 \mathrm{mg} / \mathrm{L} \mathrm{O}_{2}$ ) (Figura 9).

Butzke (2013), realizou um estudo no córrego Pintado, afluente do rio Machado que corta o município de Ji-Paraná, no estado de Rondônia, verificou valores abaixo de 4,0 mg/L. Assim como, Navqi et al. (2015) e Costa et al. (2015) estudaram a qualidade da água de cursos d'água próximos a áreas urbanas em outras regiões do país. A concentração mínima de ODA encontrada neste estudo foi 4,0 mg/L, e referese ao ponto 2 (córrego Taboca no mês de novembro), a provável causa seria a baixa circulação de água no 
ambiente por este ficar totalmente alagado, retendo toda a matéria orgânica carreada para o ambiente aquático, o que pode causar a diminuição na concentração de ODA devido ao processo natural de degradação da matéria orgânica por microrganismos aeróbicos (THORNTON et al., 2009; COSTA et al., 2015).

Ao comparar as concentrações de ODA dos pontos de amostragem nos diferentes períodos hidrológicos de cheia e seca, tendo como base o teste T de Student $(\alpha=0,05)$, não foram constatadas diferenças significativas $(p>0,05)$. Mas, ao correlacionar os períodos de seca e cheia, foi constatada diferença significativa $(p<0,05)$ com indicação de maior incidência no período de cheia para os pontos 3 e 5 (Figura 9). Segundo Alvani et al. (2011), Esteves (2011) e Andrade et al. (2019), diminuições nos teores do ODA estão diretamente relacionadas a quantidade de matéria orgânica proveniente de efluentes domésticos, industriais e fontes difusas, constatando que o ponto 5, um dos mais distantes da área urbana, apresentou a menor incidência de matéria orgânica no período de cheia.

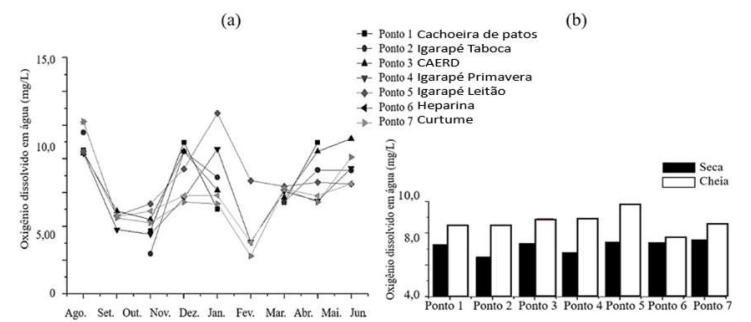

Figura 5: Gráficos expressam os resultados da concentração do oxigênio dissolvido na água ( $\mathrm{mg} / \mathrm{L})$. (a) Variações da concentração do oxigênio dissolvido na água nos pontos de amostragem e (b) Valores médios do Oxigênio dissolvido nos períodos de cheia e seca do rio Machado e córregos próximos da cidade de Presidente Médici, RO, Brasil.

Os valores da condutividade elétrica da água (CEA) dos pontos de amostragem não apresentaram diferenças $(p>0,05)$, tendo como base a análise de variância e o teste Tukey $(\alpha=0,05)$. A aferição da CEA apresentou valores médios que variaram entre 17,1 e 106,9 $\mu \mathrm{S} / \mathrm{cm}$, como apresentado na Figura 6.

De acordo com Esteves (2011) este parâmetro depende das concentrações iônicas e da temperatura, e também indica a quantidade de sais existentes na coluna d'água e, portanto, é uma medida indireta da concentração de poluentes. Em geral, níveis superiores a $100 \mu \mathrm{S} / \mathrm{cm}$ indicam ambientes impactados. No entanto, a resolução CONAMA n 357/2005 não estabelece valores máximos permissíveis para condutividade, porém a CETESB (2016) considera que valores de CEA acima de $100 \mu \mathrm{S} / \mathrm{cm}$ indicam corpos hídricos impactados por cargas poluidoras urbanas, industriais e/ou agrícolas.

Durante a realização deste trabalho apenas duas amostras apresentaram valores de CEA acima de $100 \mu \mathrm{S} / \mathrm{cm}$, o ponto 4 (em outubro) e o ponto 7 (em agosto). Em ambos os casos, os referidos pontos podem estar sendo afetados, decorrente ao descarte de origem pontual, como o ponto 7 (Curtume), pode estar sendo impactado pelo efluente proveniente de uma unidade industrial.

Ao comparar os valores de CEA entre os pontos foram obtidas diferenças significativas $(p<0,05)$. As águas dos córregos apresentaram médias de CEA maiores que a calha principal, ou seja, do rio Machado durante todo ano (Figura 6). A ocupação agrícola e as atividades zootécnicas (criação de gado, equinos, 
suínos) realizadas no entorno dos pontos 4 e 7 podem estar acelerando o processo de poluição/contaminação deste corpo d'água (BELUTTA, 2009). O valor encontrado em agosto no ponto 7 (Curtume) foi $100 \mu \mathrm{S} / \mathrm{cm}$, porque no momento da aferição ocorreu descarte do efluente da empresa na calha principal. Em outubro foi verificado um valor de CEA de $109 \mu \mathrm{S} / \mathrm{cm}$ no ponto 4, tanto a calha hídrica quanto a capacidade de depuração podem estar colaborando com o valor elevado da CEA. Estes valores altos de CEA podem também indicar alto grau de decomposição de matéria orgânica, sendo, portanto, uma maneira de se avaliar a disponibilidade de nutrientes nos ecossistemas aquáticos (ESTEVE, 2011).

Ao se correlacionar o período de seca e cheia, tendo como base o teste T de Student $(\alpha=0,05)$, não foram constatadas diferenças ( $p>0,05)$, com tendência a serem maiores na estação seca $(p>0,05)($ Figura 6). Os valores de CEA foram mais elevados na água dos córregos do que na calha principal, decorrente ao menor volume de água e menor capacidade de depuração retendo uma maior carga de íons no seu curso. Esteves (1998) comenta que em regiões tropicais os valores de CEA nos ambientes aquáticos estão relacionados às características geoquímicas e às condições climáticas (cheia e seca) da região onde se localizam.

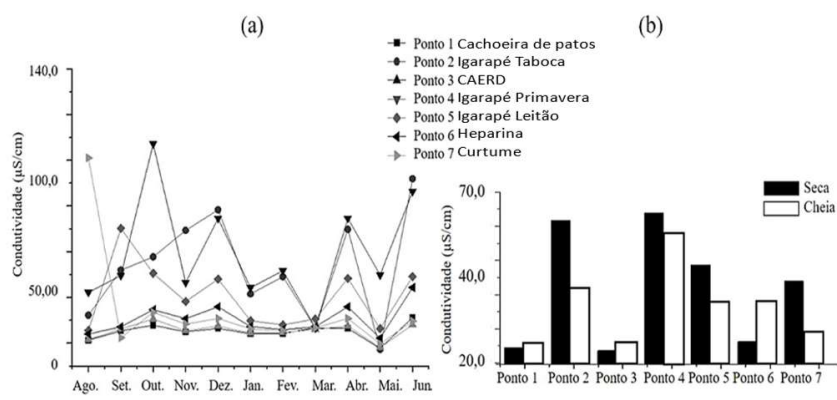

Figura 6: Gráficos expressam os resultados da condutividade elétrica na água $(\mu \mathrm{S} / \mathrm{cm})$. (a) Variações da condutividade da água nos pontos de amostragem e (b) Valores médios da condutividade da água nos períodos de cheia e seca do rio Machado e córregos próximos da cidade de Presidente Médici, RO, Brasil.

Os valores da transparência da água dos pontos de amostragem não apresentaram diferenças ( $p>0,05)$, tendo como base a análise de variância e o teste Tukey $(\alpha=0,05)$. A aferição apresentou valores médios que variaram entre 4,8 e $80,9 \mathrm{~cm}$, como apresentado na Figura 7. Vale destacar que a resolução CONAMA n³57/2005 não estabelece valores máximos permissíveis para transparência da água. No rio Machado e seus tributários foram observados maior transparência nos meses de junho, agosto e setembro, pois houve menor vazão e águas mais calmas favorecem a deposição do material particulado, aumentando a transparência da água e permitindo maior penetração da luz solar (ROCHA et al., 2015). Este fenômeno ocorre na maioria dos grandes rios brasileiros como o São Francisco, Tapajós, Araguaia e Tocantins (SANTIAGO et al., 2015). Resultado semelhante também foi encontrado por Horbe et al. (2005) ao estudar o rio Puraquequara, localizado na zona rural leste do município de Manaus, estado do Amazonas.

Ao comparar os resultados de transparência nos períodos de cheia e seca, tendo como base o teste T de Student $(\alpha=0,05)$ não foram encontradas diferenças ( $p>0,05)$. Porém, ao comparar os períodos cheia e seca foi encontrada diferença $(p<0,05)$ entre os pontos de amostragem, de modo que nos meses de seca as águas apresentaram-se mais transparentes que no período das cheia $(p<0,05)$ (Figura 7). Foi verificada maior transparência no período de seca devido uma menor concentração de matéria orgânica na água. 
Segundo Terra et al. (2010), com o aumento da precipitação há consequente aumento dos sólidos em suspensão decorrente do transporte de material alóctone, ocasionando redução nos valores da transparência nos meses chuvosos. Rocha et al. (2015) também atribuíram às chuvas o decréscimo da transparência, observando dinâmica de valores menos elevados em setembro, com aumento de outubro a novembro e nova redução a partir de junho.

(a)

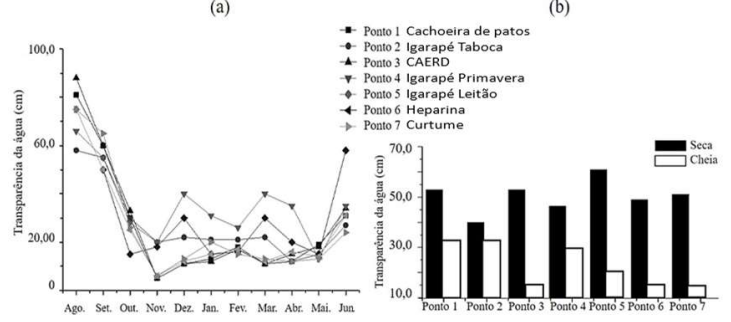

Figura 7: Gráficos expressam os resultados da transparência da água $(\mathrm{cm})$. (a) Variações da transparência da água nos pontos de amostragem e (b) Valores médios da transparência da água nos períodos de cheia e seca do rio Machado e córregos próximos da cidade de Presidente Médici, RO, Brasil.

Os valores da concentração amoniacal total da água (CAT) dos pontos de amostragem não apresentaram diferenças $(p>0,05)$, tendo como base a análise de variância e o teste Tukey $(\alpha=0,05)$. A aferição da CAT apresentou valores médios que variaram entre 0,01 e 3,6 mg/L, como apresentado na Figura 8. Neste estudo, considerou-se o nível limitante de íon amônio estabelecido para o pH $\leq 7,5$. Esteves (2011) cita que em limnologia, quando se encontra referências sobre a concentração de íon amônio, na maioria dos casos estão relacionadas às concentrações de duas formas de nitrogênio amoniacal $\left(\mathrm{NH}_{4}{ }^{1+} \mathrm{e}\right.$ $\mathrm{NH}_{3}$ ). Assim sendo, a Resolução 357/2005 do CONAMA se refere ao nitrogênio amoniacal total com valores correspondentes a 3,7 mg/L N para $\mathrm{pH} \leq 7,5 ; 2,0 \mathrm{mg} / \mathrm{L} \mathrm{N}$ para $7,5<\mathrm{pH} \leq 8,0 ; 1,0 \mathrm{mg} / \mathrm{L}$ para $8,0<\mathrm{pH}<8,5$.

Segundo Souza Filho et al. (2020), os valores naturais da CAT em águas superficiais são baixos, cerca de $1,0 \mathrm{mg} / \mathrm{L}$. Os valores da CAT obtidos neste trabalho foram menores que $1,0 \mathrm{mg} / \mathrm{L}$ durante todo o período de avaliação, indicando que os pontos da coleta no decorrer do estudo não estavam antropizados com relação ao teor de amônia. Conquanto, estudos têm mostrado que a presença de amônia é responsável em grande parte pela degradação da qualidade das águas fluviais, afetando o equilíbrio das comunidades aquáticas (BRESSANE et al., 2013). A amônia ocorre naturalmente nos corpos d'água e tem origem na degradação de compostos nitrogenados, na matéria orgânica do solo e da água, na excreção de organismos e na redução do gás nitrogênio $\left(N_{2}\right)$ (ESTEVES, 2011; SOUZA FILHO et al., 2020). A amônia é um importante nutriente para a manutenção da vida, porém, seu excesso pode ser acumulado nos tecidos do corpo dos organismos aquáticos, podendo causar efeitos secundários, como alteração do metabolismo ou aumento do $\mathrm{pH}$ (TORRES et al., 2020).

O nitrogênio amoniacal utilizado como base de fertilizantes também constitui um fator de aumento das concentrações de amônia na água (SOUZA FILHO et al., 2020). Os compostos nitrogenados frequentemente são usados para indicar o tempo de persistência dos agentes poluentes, em outras palavras, aponta a idade da carga poluidora. Desses compostos, a presença de amônia pode estar relacionada à recente poluição por esgotos domésticos e/ou industrial (MACÊDO, 2001; BRESSANE et al., 
2013).

Pode ser observado que os pontos um, dois, três, pontos mais próximos a área urbana são pontos com mais poluição difusa, introduzida pela área urbana, ou carreamento a montante. Ao comparar as concentrações amoniacais nos períodos de cheia e seca, tendo como base o teste T de Student $(\alpha=0,05)$, não foi encontrada diferença $(p<0,05)$ entre os pontos de amostragem. Porém, quanto à sazonalidade, os valores foram mais elevados no período de seca (Figura 8). Apesar de não haver diferença significativa, é nítido o elevado valor de amônia encontrado no ponto 7 mostrando um tratamento de esgoto ineficiente (Curtume no mês de agosto). Segundo Araújo et al. (2013) e Cardoso et al. (2013), isso pode ser devido à recente poluição por esgotos domésticos ou industriais, corroborando com o presente estudo devido à verificação de descarte direto de efluente. A baixa concentração de amônia registrada na cheia pode estar relacionada ao $\mathrm{pH}$ levemente ácido, característico da bacia amazônica, que também contribui para neutralização de possíveis compostos derivados de atividades agropecuárias (BARROS et al., 2010; CARDOSO et al., 2013).

(a)

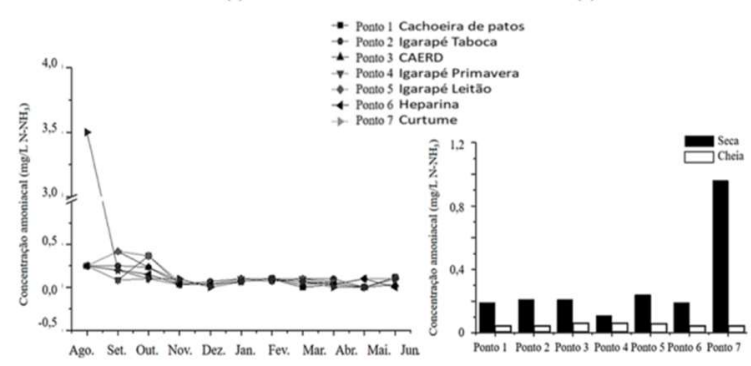

Figura 8: Gráficos expressam os resultados da concentração amoniacal na água ( $\left.\mathrm{mg} / \mathrm{L} \mathrm{N}-\mathrm{NH}_{3}\right)$. (a) Variações da concentração amoniacal na água nos pontos de amostragem e (b) Valores médios da concentração amoniacal na água nos períodos de cheia e seca do rio Machado e córregos próximos da cidade de Presidente Médici, RO, Brasil.

Fica observado que os pontos mais críticos do trabalho foram os mais próximos a área urbana que é comum em regiões sem tratamento esgoto eficiente (SPERLING, 2014), seja pela poluição, diversas fontes, seja pela jusante, e a percolação da água é o possível lançamento de efluentes doméstico, agrícolas ao longo do rio, nos municípios, a falta de tratamento adequado (ESTEVES, 2011; WU, 2018).

Pontos 2 Córrego Taboca, ponto 3 Captações de água do município, ponto 4 Córrego Primavera e ponto 5 sendo mais afastado da área urbana que o ponto 4, mas devido ponto 4 ser montante influencia no ponto 5 Córrego Leitão. Ponto 5, próximo a extração de areia, suinocultura, balneário e lacticínio, sendo que é uma área próxima à calha do Rio Machado, então segundo (ESTEVES, 2011; ANDRADE et al., 2019), áreas próximas a rios normalmente tem lençol freático fácil percolação e infiltração, e são áreas que inundam, dificultando sistema de esgoto, principalmente tanque sépticos e fossas negras que é irregular, normalmente, a contaminação do efluente com o rio, e possivelmente lançamentos direto clandestinos no rio (HURTADO et al., 2018).

Ponto 4, próximo à área urbana, tem pastagem, agricultura e produção de café, teve maiores altas de coliformes totais no período chuvoso e seco, principalmente no período chuvoso, pode ter sido pelo carreamento de matéria orgânica e sólidos dissolvidos, e grande volume de água por poluição difusa e 
diversa fontes, dos centros urbanos nas cidades próximas. No mês de junho teve os menores valores por ser período seca menor índice de carreamento e vazão do rio, já o mês de fevereiro teve os maiores valores sendo o período chuvoso, estaticamente comprovado com o teste Tukey.

Uso de águas para recreação contato primário, Balneabilidade, exemplo natação e mergulho. Avaliação dos parâmetros, são indicados com padrões microbiológicos, e confrontado com os valores préestabelecidos em lei e normas vigentes, o contato do banhista com água contaminada por bactérias, vírus e protozoários, acarreta doenças de veiculação hídrica (CETESB, 2020). O aumento de ocupações sem infraestrutura devido à instalação de famílias às margens de rios, lagoas e praias, vem afetando diretamente os ecossistemas aquáticos. E a falta de saneamento básico: com o escoamento dos poluentes nos recursos hídricos principalmente poluição difusa de diversas fontes da área urbana. Eles contribuem para a deterioração do meio ambiente Fatores como clima, práticas recreativas e fluxo de turistas refletem na sobrecarga sazonal de recursos naturais, podendo causar aumentos em coliformes totais e termotolerantes e serviços públicos, como saneamento e outros desequilíbrios socioambientais (ALVES, 2019).

Ponto 2 e 4 estiveram maiores valores de condutividade elétrica, tanto no período seca e chuvoso, os pontos próximos área urbana possível influência de solido dissolvidos, e lançamentos de efluentes agrícolas ou domésticos das áreas próximas principalmente de compostos inorgânicos, aumenta concentrações iônicas, alterações e modificações químicas na água. Ponto 7 Curtume, teve maior valor de concentração de nitrogênio amoniacal, no mês de setembro, devido a um lançamento pontual, os demais ficaram dentro da normalidade do teste Tukey, mas esse valor foi $3,6 \mathrm{mg} / \mathrm{L}$, o que verifica possível sistema de tratamento ineficiente, mas há necessidade de mais amostras, para a comprovação, devido a ter sido uma amostra em setembro do ano, que o valor deu acima da média amostral.

Possível relação da cheia histórica do rio machado afluente do rio madeira 11,62 metros dia 27/02/2014 Agência Nacional de Águas (ANA), Rio madeira por sua vez 19.14 metros dia 17/03/2014 (ANA), e da seca histórica no rio machado 6 metros no dia 14/09/2020 (ANA), seca histórica rio madeira 1.88 metros segundo Serviço Geológico do Brasil do Brasil (CPRM, 2020) no dia 16/10/2020, uma possível influência direta ou indireta nos parâmetros limnológicos e microbiológicos dos sete pontos de coleta, Foram coletadas amostras mensais no período de setembro de 2014 a junho de 2015.

Monitoramento dos sete pontos, para avaliar a situação do município mesmo depois da instalação da rede de esgoto e tratamento pela CAERD em 2017, verificar e validar os parâmetros para avaliar a qualidade limnológica e microbiológica dos pontos de coleta de água, melhorou, com a instalação da rede e tratamento de esgoto e a eficiência da adesão da população colaborou para melhora da qualidade dos pontos (CAERD, 2017).

Em relação aos resultados obtidos da análise de coliformes totais, mostraram que os pontos de amostragem estavam de acordo com a legislação. Entre os meses de setembro a janeiro, e de fevereiro a junho, 76 e $56 \%$ das amostras apresentaram-se abaixo de $5.000 \mathrm{NMP} / 100 \mathrm{~mL}$, respectivamente (Tabela 3). Conforme preconizado no decreto $n^{\circ} 7903 / 97$ da Secretaria de Desenvolvimento Ambiental (SEDAM), 
estavam abaixo do limite de $80 \%$. Entretanto, as taxas de coliformes totais apresentaram-se mais altas nos meses de novembro e janeiro. Porém, os meses com maior incidência pontual foram novembro, fevereiro e abril (Tabela 4). Barbosa (2012) ao estudar a bacia hidrográfica do Rio Pirarara, afluente do Rio Machado, no município de Cacoal, estado de Rondônia, encontrou índices de coliformes totais que variaram entre 1635 NMP/100 e 5930 NMP/100 mL. No presente estudo 60\% das amostras encontravam-se acima dos valores indicados por Barbosa (2012), estes por sua vez variaram entre 9300 NMP/100 e 1500000 NMP/100 mL. Em estudo realizado por Zuffo et al. (2013) nas bacias hidrográficas do Mamoré, Madeira, Jamari, Machado e Guaporé, atestaram a presença de coliformes totais que variaram de 500 a $1600 \mathrm{NMP} / 100 \mathrm{~mL}$. Na presente pesquisa $~ 80 \%$ das amostras encontravam-se acima dos valores indicados por Zuffo et al. (2013), tais valores variaram entre $2100 \mathrm{NMP} / 100$ e $1500000 \mathrm{NMP} / 100 \mathrm{~mL}$.

Os valores da incidência de coliformes totais da água dos pontos de amostragem não apresentaram diferenças $(p>0,05)$, tendo como base o teste Tukey $(\alpha=0,05)$ (Figura 9). No que se refere a maior incidência de coliformes totais em novembro, os pontos 3 e 4 (córrego Primavera e Estação de Tratamento da CAERD) podem ter sofrido influência da localização, próximas a área urbana, podendo ainda a contaminação ter sido proveniente da degradação ocorrida a sua circunvizinhança, em decorrência ao desenvolvimento de atividade agropecuária (COSTA et al., 2015). Outro agravante do ponto 3 é o fácil acesso, que permite sua utilização para recreação de contato primário. Quanto ao ponto 4, cabe destacar a incidência de atividade agrícola próxima ao seu leito.

O ponto 1 (córrego Taboca) tem seu curso localizado em área rural, tendo como atividade principal, a criação extensiva de bovinos. Dentre os afluentes analisados, é o que apresenta maior conservação da mata ciliar, proximamente a calha principal, o rio Machado. Entretanto, a atividade agropecuária ao seu redor favorece o carreamento para o córrego de microrganismos depositados no solo pelo gado, assim como encontrado por Johan et al. (2010), mas principalmente a área a leste da rodovia RO-135, pois não há incidência de mata ciliar em suas margens. Esta questão de elevada incidência de atividade agropecuária também se aplica à região próxima ao ponto 7 (Curtume). Outra questão verificada no ponto 2 é, além de sua pequena calha, a sua limitada capacidade de depuração, que provoca o acúmulo dos contaminantes carreados para o seu leito, assim como encontrado por Britto et al. (2011). O ponto 7 pode ainda estar sofrendo influência das fossas implantadas por uma Associação esportiva em uma de suas margens, pois não se sabe ao certo se estão corretamente vedadas.

Segundo Costa et al. (2015) o dejeto de animais, depositado no solo representa risco de contaminação das fontes de água, uma vez que esses animais são reservatórios de diversos microrganismos. Certamente, a agricultura e a pecuária são atividades economicamente indispensáveis na produção de alimentos. Tanto uma quanto a outra tem o espaço físico como uma necessidade imediata. Isso faz do desmatamento a primeira consequência, seguido da deposição de resíduos agrícolas e animais, resultando em alterações no meio ambiente (ANDRADE et al., 2019).

Outra prioridade para a agricultura e pecuária é o suprimento de água, o que conduz o desenvolvimento dessas atividades proximamente a rios e lagos, como verificado nos pontos de 
amostragem deste estudo e também por Moreira et al. (2009) e Hagemann et al. (2015). Atividades de forrageamento intensivo ou semi-intensivo bem como o manejo agrícola com o uso de produtos que visam o aumento da produção, na intensificação tem-se o manejo adequado do solo e da forrageira, o que beneficia todo o ecossistema, assim uso não técnico das atividades forrageiras desgastam gradualmente 0 solo exposto a escorrimentos superficiais da água da chuva (FRANCO et al., 2015). Nos dois casos há entrada adicional de material edáfico que carrega matéria orgânica, inorgânica e eventuais compostos químicos. Essas alterações químicas e ecológicas no sistema aquático conduzem ao desequilíbrio dos corpos d'água, provenientes da ação antrópica (MARENGO et al., 2006; FERREIRA et al., 2007; DUBOIS; JACOB, 2016).

Ao comparar a incidência de coliformes totais nos períodos de cheia e seca em relação aos pontos de amostragem, constatou-se diferença $(p<0,05)$, tendo como base o teste $T$ de Student $(\alpha=0,05)$. Evidenciou que no período de cheia a incidência de coliformes totais foi maior $(p<0,05)$ (Figura 9). A presença em elevadas quantidades de coliformes totais é comum em rios que passam por locais densamente urbanizados, como destacado por Wilbers et al. (2014), ao estudar a qualidade da água do rio Mekong no sul do Vietnã, e Mesquita et al. (2014), ao realizar análises físico-químicas e microbiológicas da água do córrego Preto em Cruzeiro do Sul, estado do Acre, observaram maiores concentrações de coliformes totais em pontos localizados dentro de áreas urbanizadas. Quanto ao presente estudo, os pontos 3 e 4 estão localizados bem próximos a área urbana, podem ter sofrido influência do elevado índice pluviométrico no período em estudo, que provoca o carreamento de contaminantes de origem difusa de acordo com as constatações de Lemos et al. (2010).

O estudo conduzido por Vasconcelos et al. (2002) mostrou que houve correlação positiva $(p<0,05)$ entre o índice de coliforme total e precipitação pluviométrica. Também Emiliani et al. (1998), Lemos et al. (2010) e Morais et al. (2015) constataram que o número de coliformes está diretamente relacionado ao nível hidrométrico (período de cheia), devido ao carreamento de matéria orgânica e inorgânica, que propicia elevada concentração de nutrientes favorecendo o desenvolvimento de bactérias. É importante lembrar que a presença de coliformes totais, em alguns casos, pode não ser indicativa de contaminação fecal porque participam deste grupo bactérias cuja origem direta não é exclusivamente entérica (SOUZA; NUNES, 2017). Cabe destacar que o parâmetro de coliformes totais ocorrem naturalmente no solo, na água e em plantas. Por isso, na avaliação da qualidade de águas naturais, os coliformes totais têm valor sanitário limitado e sua aplicação restringe-se praticamente à avaliação da qualidade da água tratada e distribuída (TARGA et al., 2012; SILVEIRA et al., 2018).

Tabela 2: Valores mensais de coliformes totais (decimal NMP/100mL) por ponto de amostragem do rio Machado e córregos próximos da cidade de Presidente Médici, RO, Brasil.

\begin{tabular}{|c|c|c|c|c|c|c|c|c|c|c|}
\hline ontos & et. 2014 S & ut. 2014 & ov. 2014 N & ez. 2014 & an.2015 & ev. 2015 & ar. $2015^{\text {M }}$ & br. 2015 & ai. $2015^{M}$ & un. 2015 \\
\hline & $1,6 \times 10^{4}$ & $1,6 \times 10^{5}$ & $9,0 \times 10^{3}$ &, $5 \times 10^{3}$ & $1,2 \times 10^{5}$ & $1,0 \times 10^{4}$ & $1,0 \times 10^{4}$ & $1,1 \times 10^{4}$ & $2,1 \times 10^{4}$ &, $6 \times 10^{3}$ \\
\hline &, $2 \times 10^{2}$ & $1,0 \times 10^{5}$ & $4,6 \times 10^{5}$ & $4,6 \times 10^{4}$ & $4 \times 10^{3}$ & $0 \times 10^{3}$ &, $2 \times 10^{3}$ & $1,3 \times 10^{5}$ & $1,8 \times 10^{4}$ & $9 \times 10^{3}$ \\
\hline & $0 \times 10^{2}$ & $6 \times 10^{3}$ & $4,5 \times 10^{5}$ & $1,2 \times 10^{4}$ & $1,1 \times 10^{5}$ & $1,5 \times 10^{4}$ & $0 \times 10^{2}$ & $1,1 \times 10^{4}$ & $1,5 \times 10^{4}$ & $5 \times 10^{3}$ \\
\hline
\end{tabular}




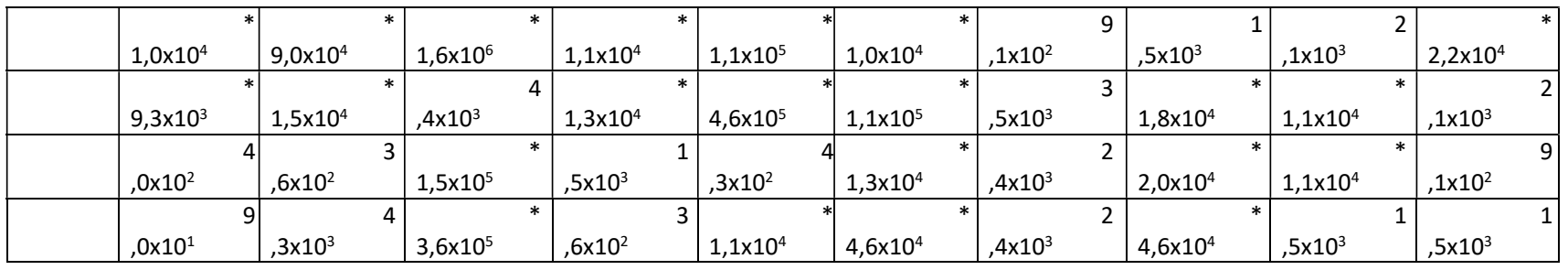

* Amostragem com valor superior ao estabelecido pelo decreto $n^{\circ} 7903 / 97$.

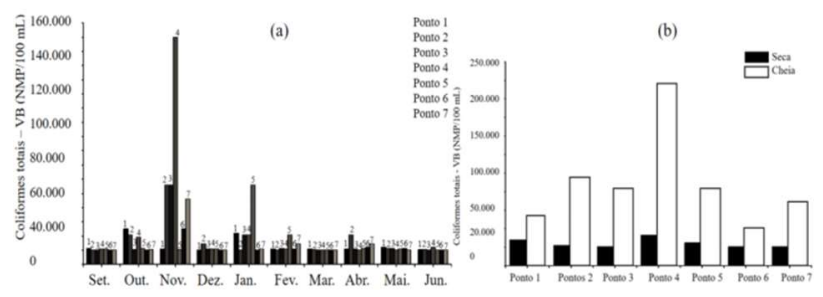

Figura 9: Gráficos expressam os resultados da detecção de coliformes totais. (a) Valores de coliformes totais dos pontos de amostragem e (b) Valores médios de coliformes totais nos períodos de cheia e seca do rio Machado e córregos próximos da cidade de Presidente Médici, RO, Brasil.

Em relação aos resultados obtidos da análise de termotolerantes, mostraram que apenas as amostras bimestrais dos pontos 1 a 6, entre os meses de janeiro e fevereiro, estavam acima do padrão estabelecido pela legislação (Tabela 4). Apresentaram-se conforme o limite estabelecido, 33,3\% das amostras de setembro e outubro, $50 \%$ de novembro e dezembro, $66 \%$ de março a abril e $41,6 \%$ de maio a junho. Portanto, todas as amostras, exceto pelo período de janeiro e fevereiro, estavam de acordo com a Resolução n 357 de 17 de março de 2005 do CONAMA.

O ponto 4 (Córrego Primavera) apresentou menor incidência de coliformes termotolerantes. Cabe destacar que, mesmo verificando os maiores valores no mês de novembro, os meses com maior incidência pontual além do limite determinado pelo CONAMA (2005) foram janeiro, fevereiro, março e maio (Tabela 4). O maior aporte pontual nos meses destacados, não compromete o argumento de que a incidência de coliformes termotolerantes é decorrente do alto índice pluviométrico, pois este período provoca aumento da calha, que recebe cargas de material orgânico tanto de origem agrícola quanto urbana, como em muitos casos o transbordamento de fossas implantadas em locais irregulares (TARGA et al., 2012).

Sem dúvida a ocorrência de coliformes termotolerantes em números que excedem ao mínimo estabelecido pelo CONAMA (2005) indica contaminação de origem ambiental e fecal, um caso de amostra pontual e individual (SILVA et al., 2014). Atividades antrópicas influenciam o ambiente em diversos aspectos, e muitos deles têm potencial para impactar negativamente os recursos naturais, e ademais, os recursos hídricos são os mais susceptíveis de serem afetados (OLIVEIRA et al., 2015).

Os valores da incidência de coliformes termotolerantes da água dos pontos de amostragem não apresentaram diferenças $(p>0,05)$, tendo como base o teste Tukey $(\alpha=0,05)$ (Figura 9). No mês de outubro foi verificada maior incidência de coliformes termotolerantes nos pontos 1 e 2 , em decorrência das chuvas pontuais características do início do período de cheia, porque as primeiras chuvas carreiam enormes quantidades de contaminantes de origem difusa diversas fontes, conforme abordado por Targa et al. (2012) e Silveira et al. (2018). O ponto 1 pode estar sendo influenciado pela urbanização irregular das 
cidades que o rio Machado percorre antes da cidade de Presidente Médici (Como Cacoal e Pimenta Bueno), pois conforme Prosenewicz et al. (2012) esse rio recebe lançamento de esgoto urbano sem tratamento. Em relação ao ponto 2 , como citado, mesmo que haja uma contaminação em quantidade menor que nos demais pontos, o fato da baixa capacidade de depuração e a ocorrência do acúmulo de matéria orgânica potencializa a concentração de coliformes termotolerantes (OLIVEIRA et al., 2015; FARIA et al., 2017).

No mês de novembro, a maior incidência de coliformes termotolerantes foi nos pontos 4, 5, 6 e 7 . Os maiores valores ocorridos no ponto 4 podem ser devido à ausência de tratamento de esgoto. Pode-se ainda ser mencionada a provável influência da comunidade instalada em sua proximidade. No entanto, o ponto 5 pode estar sendo influenciado pela implantação de uma suinocultura, de balneário e de algumas casas nas proximidades de seu leito. Estas residências, por sua vez, apresentam fossas sépticas e, quando não alocadas em locais apropriados, podem transbordar no período de cheia. Vale destacar que houve denúncias de que empresas estariam descartando contaminantes na calha do ponto 5 , porém, não há conhecimento da natureza de tais despejos.

O ponto 6 apresentou incidência de coliformes termotolerantes possivelmente devido à acumulação dos pontos anteriores ou por influência da empresa de extração de areia e de uma associação esportiva. As duas propriedades estão localizadas nas proximidades. Não há conhecimento se esses empreendimentos possuem banheiro químico ou banheiro séptico corretamente vedado. De qualquer forma, ambos estão localizados em faixa alagável, o que dificulta a implantação de fossas sépticas. Quanto ao ponto 7 , os números encontrados nesse ponto podem ser decorrentes do acúmulo do ponto 6 . No que tange à própria empresa, não há conhecimento pertinente à composição do seu descarte, impedindo assim, alguma afirmação de seus efeitos na bacia hidrográfica do rio Machado. A influência do homem neste parâmetro pode estar vinculada à ocupação desordenada e irregular de suas margens.

Ao comparar a incidência de coliformes termotolerantes nos períodos de cheia e seca em relação aos pontos de amostragem, constatou-se diferença $(p<0,05)$, tendo como base a teste $T$ de Student $(\alpha=0,05)$. Evidenciou que no período de cheia a incidência de coliformes totais foi maior $(p<0,05)$ (Figura 10). Alguns estudos que avaliaram a qualidade da água para fins recreativos indicaram que durante o período de cheia há um aumento na incidência de coliformes, principalmente dos termotolerantes (MORAIS et al., 2012). Mas, Silva et al. (2008) ao avaliarem a qualidade sanitária por meio da ocorrência de coliformes em águas superficiais do Rio Una - São Paulo; Souza et al. (2008) ao avaliarem os aspectos físicoquímicos e bacteriológicos da água do córrego Figueira, pertencente a Microbacia do Queima-pé, no município de Tangará da Serra, Mato Grosso; e Pontes et al. (2015), ao avaliarem a água da micro-bacia do córrego Banguelo em Bom Jesus, Minas Gerais; encontraram valores elevados de coliformes termotolerantes no período de cheia. Esse resultado estava relacionado à ocupação urbana instalada sem planejamento na região. Tais resultados corroboram com o presente estudo, em relação à ocupação irregular das margens do rio Machado, assim como a maior incidência no período chuvoso. Confirmando que agentes/dejetos agrícolas, urbanos e industriais causam contaminação ambiental.

Carvalho et al. (2012), ao estudarem os efeitos dos impactos do meio urbano na qualidade da água 
do canal São Joaquim, Belém do Pará, constataram valores de até $11 \times 10^{5} \mathrm{NMP} / \mathrm{mL}$ de coliformes termotolerantes. Segundo os autores, estes valores estão relacionados ao processo de urbanização sem planejamento e nenhuma preocupação sanitária, o que ocasionou o despejo de lixo e efluentes domésticos e industriais na sub-bacia hidrográfica do canal São Joaquim-PA. E ainda, Segundo Souza et al. (2008), Pontes et al. (2015) e Silveira et al. (2018), a falta de estrutura sanitária e sobretudo do manejo inadequado de dejeções humanas são os fatores mais importantes de contaminação dos recursos hídricos

Tabela 3: Valores mensais de termotolerantes (decimal NMP/100mL) por ponto de amostragem do rio Machado e córregos próximos a cidade de Presidente Médici, RO, Brasil.

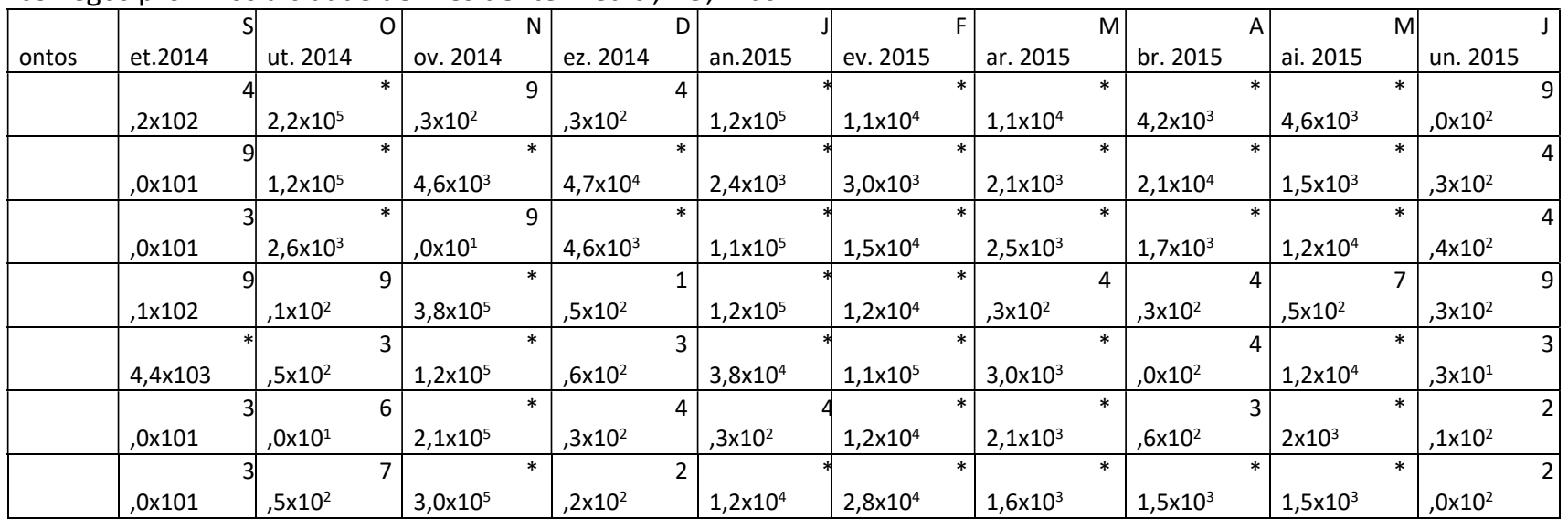

*Amostragem com valor superior ao estabelecido pela Resolução CONAMA 357/2005.

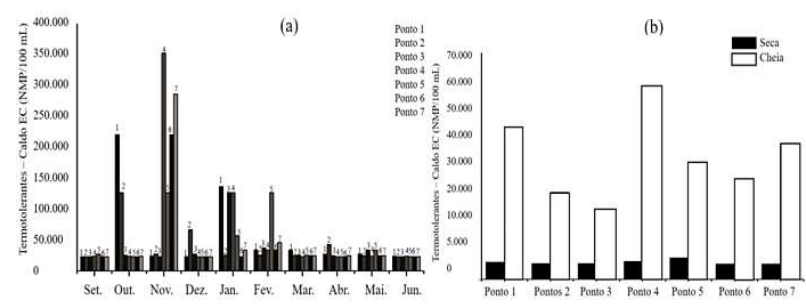

Figura 10: Gráficos expressam os resultados da detecção de termotolerantes. (a) Valores de termotolerantes dos pontos de amostragem e (b) Valores médios de termotolerantes nos períodos de cheia e seca do rio Machado e córregos próximos a cidade de Presidente Médici, RO, Brasil.

\section{CONCLUSÕES}

Foram constatadas alterações pontuais em alguns parâmetros limnológicos como $\mathrm{pH}$, condutividade elétrica e concentração amoniacal. Porém, em geral, os parâmetros limnológicos apresentaram-se de acordo os limites de variação das normatizações vigentes. A sazonalidade influenciou diretamente no $\mathrm{pH}$, temperatura, concentração de oxigênio dissolvido, transparência e concentração amoniacal principalmente nos pontos mais próximos a área urbana. Em relação ao $\mathrm{pH}, \sim 4 \%, 9$ de um total de 231 amostras apresentaram-se abaixo do estipulado pela resolução CONAMA 357/2005 de águas doce de classe 2. Para o oxigênio dissolvido, apenas uma amostra apresentou abaixo do estabelecido pela mesma legislação, duas amostras estiveram acima do limite da CETESB.

A incidência de coliformes totais e termotolerantes ficou dentro dos limites estabelecidos, exceto nos termotolerantes nas análises bimestrais de janeiro e fevereiro $91,6 \%$ que estão fora do padrão normativo, para águas de Classe 2 na CONAMA 357/2005 e do decreto 7903 (SEDAM) para coliformes 
totais. Os maiores valores de coliformes termotolerantes foram encontrados no período de cheia. Os resultados revelaram que houve incidência de bactérias do subgrupo coliformes fecais termotolerantes, devido a possível poluição difusa em diversas fontes, influenciada pela área urbana. Este dado permite inferir que o alto valor de coliformes se deve ao recebimento de esgotos pelo rio e alterações ambientais existentes em algumas áreas próximas da cidade de Presidente Médici.

O estudo indica que há necessidade de gerar informações sobre a qualidade das águas dos rios e córregos no município de Presidente Médici e no estado de Rondônia, sobretudo, dos cursos d'água próximos as áreas urbanas. Porque são informações importantes para saúde e abastecimento público, bem como a saúde ambiental e também de grande valia no meio técnico-científico. Cabe salientar que as informações encontradas também apontam carência de tratamento de esgotos domésticos e industriais em cursos d'água próximos a áreas urbanas.

Ficam evidenciados nos dados limnológicos e microbiológicos que os pontos próximos a área urbana devido a poluição difusa, são os pontos com os valores mais fora do padrão das normas e recomendado na literatura, esses valores foram acima aos pontos, exceto em setembro concentração amoniacal, poluição pontual do curtume foi elevada, com atividades agropecuárias, e industriais como curtume e fabricação de composto para refino de Heparina, que são poluição pontual, fica para futuros estudos avaliar o impacto das áreas urbanas sobre o Rio Machado e seus afluentes em Presidente Médici.

\section{REFERÊNCIAS}

ABREU, C. H. M.; CUNHA, A. C.. Qualidade da água em ecossistemas aquáticos tropicais sob os impactos ambientais no baixo Rio Jari-AP: revisão descritiva. Biota Amazônia, v.5, n.2, p.119,131, 2015. DOI: https://doi.org/10.18561/21795746/biotaamazonia.v5n2p119-131

ALVES, B. L. A.; NASCIMENTO, V. G. S.; PEREIRA-JÚNIOR, A.. Qualidade e uso da água de um igarapé, uma nascente e um reservatório na zona rural do município de Nova Timboteua PA (Brasil). Revista Brasileira de Meio Ambiente, v.7, n.1, p.48-69, 2019. DOI:https://doi.org/10.5281/zenodo.3470639

ALVES, L. S. Análise da Balneabilidade das Praias do Rio Vermelho em Salvador, Bahia: Paciência, Santana e Buracão. Revista Científica Multidisciplinar Núcleo do Conhecimento, v.3, n.1, p.92-102, 2018.

ALVES, R. I. S.. Parâmetros limnógicos, metais, bioagentes patogênicos na Bacia Hidrográfica do Pardo: avaliação de risco à saúde humana e análise multivariada. Tese (Doutorado em Ciência: Saúde Ambiental) - Universidade de São Paulo, Ribeirão Preto, 2013.

ANA. Agência Nacional de Águas. Conjuntura dos recursos hídricos: Informe 2016. Brasília: ANA, 2016.

ANDRADE, L. R.; MOREIRA, J. P. P. C.; SANTOS, A. M. Temporary Analysis of Land Use and Coverage in the Rio Boa Vista River, Ouro Preto do Oeste-RO. Caderno de Geografia, v.29, n.56, 2019. DOI: https://doi.org/10.5752/p.23182962.2019v29n56p81

ARAÚJO, M. C.; OLIVEIRA, M. B. M.. Monitoring of water quality of a stream at the Federal University of Pernambuco, Brazil. Revista Ambiente \& Água, v.8, n.3, 2013. DOI: http://doi.org/10.4136/ambi-agua.1192
BARBOSA, L. S.. Análise da qualidade da água e o processo de uso e ocupação das terras na bacia hidrográfica do Rio Pirarara no município de Cacoal-Rondônia. Dissertação (Mestrado em Geografia) - Universidade Federal de Rondônia, Porto Velho, 2012.

BARBOSA, L. S.; SILVA FILHO, E. P.. Influência do uso e ocupação na qualidade da água do rio Pirarara, afluente do rio Machado, Rondônia/Brasil. Revista Ibero-Americana de Ciências Ambientais, v.9, n.7, 2018. DOI: http://doi.org/10.6008/CBPC2179-6858.2018.007.0030

BARROS, Y. J.; KUMMER, L.; ORRUTÉA, A. G.; MELLEK, J. E.; JESUS, M. R. G.; ANDRETTA, R. L.; FAVARETTO, N.. Influência de diferentes usos e ocupações do solo na qualidade da água dos córregos Piarara e Tamarupá, em Cacoal - RO. Revista de Ciências Agrárias, v.53, n.1, p.102-107, 2010 DOI: https://doi.org/10.4322/rca.2011.01

BRASIL. Ministério do Meio Ambiente. Resolução no 430, de 13 de maio de 2011. Dispõe Sobre as Condições e Padrões de Lançamento de Efluentes, complementa e Altera a Resolução no 357, de17 de Março de 2005. Nacional do Meio Ambiente. Brasília-DF: CONAMA, 2011.

BRASIL. Fundação Nacional de Saúde. Manual prático de análise de água. 2.ed. Brasília: FUNASA, 2006.

BRASIL. Ministério da Saúde. Manual técnico de diagnóstico laboratorial de Salmonella spp.: diagnóstico laboratorial do gênero Salmonella Brasília: Ministério da Saúde, 2011.

BRESSANE, L. W.; SANTOS, R. M.; MENDES, R. B.. Análise da comunidade fitoplanctônica na represa de Furnas em Barranco Alto-MG. Fórum Ambiental da Alta Paulista, v.9, n.2, 2013. DOI: 
BRITTO, L. C. F.; MACHADO FILHO, L. C. P.; HOTZEL, M. J.; LABARRÈRE, J. G.. The effect of different offers shading in the dispersion of the feces of cattle in the pasture. Revista Brasileira de Agroecologia, v.6, n.1, p.137-146, 2011.

BUTZKE, K.. Avaliação limnológica de um córrego impactado pela urbanização da cidade de Ji-Paraná (Rondônia): córrego pintado. Monografia (Graduação em Engenharia Ambiental) - Universidade Federal de Rondônia, Ji-Paraná, 2013.

CAERD. Companhia de águas e esgotos do estado de Rondônia. Relatório anual: exercício 2017 Informação ao Consumidor Decreto 5.440/2005, 2017

CARDOSO, R. S.; NOVAES, C. P.. Variáveis limnológicas e macroinvertebrados bentônicos como bioindicadores de qualidade de água. Revista Nacional de Gerenciamento de Cidades, v.1, n.5, 2013. DOI: http://doi.org/10.17271/23188472152013510

CARVALHO, J. R. F., LIMA, A. C. M., COUTINHO, N. B., FERNANDES, L. L.. Urbanização e Meio Ambiente: efeito dos impactos do meio urbano na qualidade da água de canais naturais: o caso do canal São Joaquim. Belém: UNAMA, 2012.

CETESB. Companhia Ambiental do Estado de São Paulo. Significado Ambiental e Sanitário das Variáveis de Qualidade das Águas e dos Sedimentos e Metodologias Analíticas e de Amostragem Apêndice E. CETESB, 2016.

CETESB. Companhia Ambiental do Estado de São Paulo. Companhia de Tecnologia de Saneamento Ambiental. Variáveis de qualidade das águas. São Paulo: CETESB, 2001.

CONSERVA, C. S.; ANDRADE, L. M. S.; SANT'ANA, D. R.; CARVALHO, D. J.; COSTA, M. E. L.; KOIDE, S.. Olhares sobre a drenagem em Brasília: expansão urbana e infraestrutura socioecológica na Serrinha do Paranoá, DF. Mix Sustentável, v.5, n.2, p.149-164, 2019. DOI:

http://dx.doi.org/10.29183/2447-3073.MIX2019.v5.n2.149164

COSTA, A. L. S.; RODRIGUES, M. S.; RICCI, F.. Caracterização da piscicultura na região de Ariquemes, no estado de Rondônia. Revista de Geografia Agrária, v.10, n.20, p.512537, 2015.

CUNHA, A. C.; PINHEIRO, L. A. R.; CUNHA, H. F. A.; SCHULZ, H. E.; BRASIL JUNIOR, A. C. P.; SOUZA, E. B.. Simulação da hidrodinâmica e dispersão de poluentes com monitoramento virtual no rio Matapi-AP. Revista de Estudos Ambientais, v.13, n.2, p. 18-32, 2011. DOI: http://dx.doi.org/10.7867/1983-1501.2011v13n2p18-32

DUBOIS, N.; JACOB, J.. Molecular Biomarkers of Anthropic Impacts in Natural Archives: A Review. Frontiers in Ecology and Evolution, v.4, 2016. DOI:

http://dx.doi.org/10.3389/fevo.2016.00092

EMBRAPA. Empresa Brasileira de Pesquisa Agropecuária. Avaliação da qualidade das águas: manual prático. Brasília,: Embrapa Informação Tecnológica, 2004.

EMILIANI, F.; GONZÁLES, S. M. P.. Bacteriological quality of Bendetti Lake (Santo Tome, Santa Fé Province, Argentina) and associated enviromental variables. Revista Argentina de Microbiología, v.30, p.30-38, 1998.

ESTEVES, F. A.. Fundamentos de Limnologia. 3 ed. Rio de Janeiro: Editora Interciência, 2011.

ESTEVES, F. A.. Fundamentos de Limnologia. 3 ed. São
Paulo. Editora Interciência, p.259-281, 2011.

ESTEVES, F.A. Fundamentos de Limnologia. 2 ed. Rio de Janeiro: Interciência, 1998.

FARIA, M. M.; ARAÚJO, W. F.; GONÇALVES, R.; WANKLER, F. L.; EVANGELISTA, R. A. O.; SANDER, C. Morphometric characterization of the Igarapé Carrapato river basin. Vértices, v.19, n.2, p.9-22, 2017. DOI: http://doi.org/1010.5935/1809-2667.v19n22017p9-22

FRANCO, G. B.; BETIM, L. S.; MARQUES, E. A. G.; CHAGAS, C. S.; GOMES, R. L.. Avaliação da qualidade sanitária da água na bacia hidrográfica do rio Almada-BA. Revista Caminhos de Geografia, v.16, n.54, p.254-262, 2015.

GALVAN, K. A.; MEDEIROS, R. C.; MARTINS NETO, R. P.; LIBERALESSO, T.; GOLOMBIESKI, J. I.; ZANELLA, R. Macroscopic environmental analysis and water quality of springs in São Domingos Watershed/SC, Brazil. Revista Ibero-Americana de Ciências Ambientais, v.11, n.1, 2020. DOI: http://doi.org/10.6008/CBPC2179-6858.2020.001.0016

GOMES, J. B.; WEBLER, A. D.; AGUIAR, R. G.; AGUIAR, L. J. G.; NUÑES, M. L. A.. Conversão de florestas tropicais em sistemas pecuários na Amazônia: quais as implicações no microclima da região? Revista Brasileira de Climatologia, v.17, p.67-81, 2015. DOI: http://dx.doi.org/10.5380/abclima.v17i0.42879

GOMES, M. J. M. P.. Avaliação do Efeito da Microfauna do Tanque de Arejamento no Efluente Final. Dissertação (Mestrado em Engenharia Química) -Instituto Superior de Engenharia do Porto, Portugal.

HAN, L.; HUANG, M.; M. A.; M.; WEI, J.; HU, W.; CHOUHAN, S.. Evaluating Sources and Processing of Nonpoint Source Nitrate in a Small Suburban Watershed in China. Journal of Hydrology, v.559, p.661-668, 2017. DOI: http://dx.doi.org/10.1016/j.jhydrol.2017.04.057

HAGEMANN, S. E.; GASTALDINI, M. C. C.. Variation of rainwater quality with precipitation: application to Santa Maria city-RS. Revista Brasileira de Recursos Hídricos, v.21, n.3, p.525-536, 2015. DOI: http://doi.org/10.1590/2318$\underline{0331.011615010}$

HURTADO, F. B.; FIGUEIREDO, F. M.; COSTA, R. L.; QUEIROZ, B. Q.; PONTES, W. P.. Parâmetros limnológicos em viveiros de piscicultura semi-intensiva de tambaqui com abastecimento em disposição sequencial. Revista em Agronegócio e Meio Ambiente, v.11, n.1, p.9-30, 2018. DOI: https://doi.org/10.17765/2176-9168.2018v11n1p9-30

INPE. Instituto Nacional de Pesquisas Espaciais. Projeto Prodes: Monitoramento da Floresta Amazônica Brasileira por Satélite. 2020

KRUSCHE, A. V.; BALLESTER, R. L.; VICTORIA, M. C. BERNARDES, N. K.; LEITE, L.; HANADA, D. C.; VICTORIA, A. M.; TOLEDO, J. P.; OMETTO, M. Z.; MOREIRA, B. M.; GOMES, M. A.; BOLSON, S.; GOUVEIA NETO, N.; BONELLI, L.; DEEGAN, C.; NEILL, S.; THOMAS, A. K.; RICHEY, J. E.. Efeitos das mudanças do uso da terra na biogeoquímica dos corpos d'água da bacia do rio Ji-Paraná, Rondônia. Acta Amazonica, v.35, n.2, p.197-205, 2005. DOI: https://doi.org/10.1590/S0044-59672005000200009

LIMA, R. N. S.; RIBEIRO, C. B. M.; BARBOSA, C. C. F.; ROTUNNO FILHO, O. C.. Estudo da poluição pontual e difusa na bacia de contribuição do reservatório da usina hidrelétrica de Funil utilizando modelagem espacialmente distribuída em Sistema de Informação Geográfica. Revista de Engenharia Sanitária e Ambiental, v.21, n.1, p.139-150, 2016. DOI: https://doi.org/10.1590/s1413- 


\section{$\underline{41520201600100127676}$}

MESQUITA, F. R.; NASCIMENTO, A. U. L.; NASCIMENTO, L. O.; RIBEIRO, O. A. S.; CRAVEIRO, R. L.. Análise físico-química e microbiológica da água: estudo de caso no Balneário Córrego Preto, Cruzeiro do Sul, Acre-Brasil. Enciclopédia Biosfera, v.10, n.19, 2014.

MORAIS, G. F. O.; SANTOS, N. A.; VASCO, A. N.; BRITTO, F. B.. Manejo, aspectos sanitários e qualidade da água de cisternas em comunidades do semiárido sergipano. Gaia Scientia, v.11, n.2, p.218-230, 2017. DOI: https://doi.org/10.21707/gs.v11.n02a015

MORAIS, R. C. S.; SILVA, C. E.. Diagnóstico ambiental do balneário Curva São Paulo no rio Poti em Teresina, Piauí. Revista de Engenharia Sanitária e Ambiental, v.17, n.1, p.41-50, 2012. DOI: https://doi.org/10.1590/S141341522012000100008

NAQVI, S. M. K.; KUMAR, D. K.; SEJIAN, V.. Climate Change and Water Availability for Livestock: Impact on Both Quality and Quantity. In: SEJIAN, V.; GAUGHAN, J.; BAUMGARD, L.; PRASAD, C.. Climate Change Impact on Livestock: adaptation and Mitigation. New Delhi: Springer, 2015.

OLIVEIRA, A. J.; SANTOS, M. C. H. G.; ITAYA, N. M.; CALIL, R. M.. Coliformes termotolerantes: bioindicadores da qualidade da água destinada ao consumo humano. Atas de Saúde Ambiental, v.3, n.2, 2015.

PIRATOBA, A. R. A.; RIBEIRO, H. M. C.; MORALES, G. P.; GONÇALVES, W.. Caracterização de parâmetros de qualidade da água na área portuária de Barcarena, PA, Brasil.

Ambiente \& Água, v.12, n.3, 2017. DOI: https://doi.org/doi:10.4136/ambi-agua.1910

PONTES, P. P.; MARQUES, A. R.; MARQUES, G. F.. Efeito do uso e ocupação do solo na qualidade da água na microbacia do Córrego Banguelo. Ambiente \& Água, v.7, n.3, 2012. DOI: https://doi.org/10.4136/ambi-agua.962

PROSENEWICZ, I.; LIPPI, U. G.. Access to health services, health conditions and exposure to risk factors: perception of riparian fishermen of the Machado River in Ji-Paraná, RO. Revista Saúde e Sociedade, v.21, n.1, p.219-231, 2012.

RIBEIRO, E. A.; SANDRI, D.; BOÊNO, J. A.. Qualidade da água de córrego em função do lançamento de efluente de abate de bovino. Revista Brasileira de Engenharia Agrícola e Ambiental, v.17, n.4, p.425-433, 2013. DOI: http://dx.doi.org/10.1590/S1415-43662013000400011

ROCHA, C. H. B.; COSTA, H. F.. Variação temporal de parâmetros limnológicos em manancial de abastecimento em Juiz de Fora, MG. Revista Brasileira de Recursos Hídricos, v.20, n.2, p.543-550, 2015.

SANTIAGO, T. M. O.; REZENDE, J. L. P.; BORGES, L. A. C. BORGES, A. F.; SANTOS, A. A.. A eficácia da avaliação de impactos ambientais no Brasil. Revista Ibero-Americana de Ciências Ambientais, v.6, n.2. DOI: http://dx.doi.org/10.6008/SPC2179-6858.2015.002.0003
SANTOS, M. S.; BAGGIO FILHO, H.; ARAÚJO, A. D.; FREITAS, M. O.; COSTA, T. M.; HORN, A. H.. Análise da concentração e distribuição de metais pesados na água do rio das Velhas entre a cidade de várzea da palma e o distrito de barra do Guaicuí- MG. Revista Cerrados, v.16, n.1, p.130-158, 2018. DOI:

http://dx.doi.org/10.22238/RC2448269220171601130158

SEDAM. Secretaria de Estado de Desenvolvimento Ambiental. Decreto ${ }^{\circ}$ 7903, de 01 de julho de 1997. Regulamenta a Lei $n^{\circ}$ 547, de 30 de dezembro de 1993. Constituição do estado de Rondônia, Brasil.

SILVA, C. C.; SILVA, E. A.; TOLEDO, L. A.; LIMA, M. A. G.; MOREIRA, R.; CÂNDIDO, R.; RITÁ, F. S.; SANTOS, C. S. Análises do perfil bacteriológico das águas do ribeirão das Antas, no município de Cambuí-MG, como indicador de saúde e impacto ambiental. Revista Agrogeoambiental, n.2 p.47-51, 2014. DOI: http://dx.doi.org/10.18406/23161817v0n02014751

SILVEIRA, C. A.; CASTRO, F. B. G.; GODEFROID, R. S.; SILVA, R. C.. Microbiological analysis of Bacacheri River water, Curitiba (PR), Brazil. Revista de Engenharia Sanitária e Ambiental, v.23, n.5, p.933-938, 2018. DOI: http://dx.doi.org/10.1590/S1413-41522018163474

SOUSA, R. G. C.; SOUZA, L. A.; FRUTUOSO, M. E.; FREITAS, C. E. C.. Seasonal dynamic of amazonian small-scale frisheries is dictated by the hydrologic pulse. Boletim do Instituto de Pesca, v.43, n.2, p.207-221, 2017. DOI: http://dx.doi.org/10.20950/1678-2305.2017v43n2p207

SPERLING, M. V.. Introdução à qualidade das águas e ao tratamento de esgotos. Universidade federal de Minas Gerais, Belo Horizonte, 2014.

TARGA, M. S.; BATISTA, G. T.; DINIZ, H. N.; DIAS, N. W.; MATOS, F. C.. Urbanização e escoamento superficial na bacia hidrográfica do Córrego Tucunduba, Belém, PA, Brasil. Ambiente \& Água, v.7, n.2, 2012. DOI: http://doi.org/110.4136/ambi-agua.905

TORRES, K. M. A.; LOPES, R. B.; PASSOS, C. J. S.; PEREIRA, A. C.; MOURA, L. S.. Dominance of potentially toxic cyanobacteria on the waterfront of Santarém, Tapajós River, Brazilian Amazon. Revista Ibero-Americana de Ciências Ambientais, v.11, n.6, p.298-314, 2020. DOI: http://doi.org/10.6008/CBPC2179-6858.2020.006.0025

WILBERS, G. J.; BECKER, M.; NGA, L. T.; SEBESVARI, Z.; RENAUD, F. G.. Spatial and temporal variability of surface water pollution in the Mekong Delta, Vietnam. Science of the Total Environment, v.485-486, p.653-665, 2014. DOI: http://doi.org/10.1016/i.scitotenv.2014.03.049

WU, Z.; WANG, X.; CHEN, Y.; CAI, Y.; DENG, J.. Assessing river water quality using water quality index in Lake Taihu Basin, China. Science of The Total Environment, v.612, p.914-922, 2018. DOI: https://doi.org/10.1016/i.scitotenv.2017.08.293

A CBPC - Companhia Brasileira de Produção Científica (CNPJ: 11.221.422/0001-03) detém os direitos materiais desta publicação. Os direitos referem-se à publicação do trabalho em qualquer parte do mundo, incluindo os direitos às renovações, expansões e disseminações da contribuição, bem como outros direitos subsidiários. Todos os trabalhos publicados eletronicamente poderão posteriormente ser publicados em coletâneas impressas sob coordenação da Sustenere Publishing da Companhia Brasileira de Produção Científica e seus parceiros autorizados. Os (as) autores (as) preservam os direitos autorais, mas não têm permissão para a publicação da contribuição em outro meio, impresso ou digital, em português ou em tradução. 